\title{
Towards More Sustainable Materials for Geo-Environmental Engineering: The Case of Geogrids
}

\author{
Alessio Cislaghi ${ }^{1,2, *(1)}$, Paolo Sala ${ }^{1}$, Gigliola Borgonovo ${ }^{3}$, Claudio Gandolfi ${ }^{1}$ and Gian Battista Bischetti ${ }^{1,2}$ \\ 1 Department of Agricultural and Environmental Sciences (DiSAA), University of Milan, Via Celoria 2, \\ 20133 Milan, Italy; paolo.sala@unimi.it (P.S.); claudio.gandolfi@unimi.it (C.G.); bischetti@unimi.it (G.B.B.) \\ 2 Centre of Applied Studies for the Sustainable Management and Protection of Mountain Areas (Ge.S.Di.Mont), \\ University of Milan, Via Morino 8, Edolo, 25048 Brescia, Italy \\ 3 Department of Food, Environmental and Nutritional Sciences, University of Milan, Via Mangiagalli 25, \\ 20133 Milan, Italy; gigliola.borgonovo@unimi.it \\ * Correspondence: alessio.cislaghi@unimi.it; Tel.: +39-02-503-16903
}

Citation: Cislaghi, A.; Sala, P.; Borgonovo, G.; Gandolfi, C.;

Bischetti, G.B. Towards More Sustainable Materials for Geo-Environmental Engineering: The Case of Geogrids. Sustainability 2021, 13, 2585. https://doi.org/10.3390/ su13052585

Academic Editor: Giuseppe Cardile

Received: 22 January 2021

Accepted: 24 February 2021

Published: 28 February 2021

Publisher's Note: MDPI stays neutral with regard to jurisdictional claims in published maps and institutional affiliations.

Copyright: (c) 2021 by the authors. Licensee MDPI, Basel, Switzerland. This article is an open access article distributed under the terms and conditions of the Creative Commons Attribution (CC BY) license (https:// creativecommons.org/licenses/by/ $4.0 /)$.

\begin{abstract}
Plastic materials are widely used in geotechnical engineering, especially as geosynthetics. The use of plastic-based products involves serious environmental risks caused by their degradation. Innovative research has been focusing on biodegradable polymers of natural origin, especially on poly(lactic acid) (PLA), to reduce the use of plastics. This study aims to explore the potentiality of biopolymers for the production of geogrids, measuring the chemical and mechanical characteristics of raw materials and of prototype samples, similar to those available on the market. First, chemical composition and optical purity were determined by hydrogen nuclear magnetic resonance $\left({ }^{1} \mathrm{H}-\mathrm{NMR}\right)$ and polarimetry. Furthermore, samples of uniaxial and biaxial geogrids were custom-molded using a professional 3D printer. Mechanical properties were measured both on the filament and on the prototype geogrids. The maximum tensile resistance was $6.76 \mathrm{kN} / \mathrm{m}$ for the neat-PLA filament and $10.14 \mathrm{kN} / \mathrm{m}$ for uniaxial prototype geogrids produced with PLA-based polymer mixed with titanium dioxide. PLA-based materials showed higher tensile properties than polypropylene (PP), the most common petroleum derivative. Conversely, such biomaterials seem to be more brittle and with scarce elongation rate respect PP. Nonetheless, these results are encouraging and can support the use of PLA-based materials for innovative biodegradable geosynthetics production, especially if used in combination with live plants.
\end{abstract}

Keywords: geosynthetics; poly(lactic acid); biopolymers; geogrids; tensile strength

\section{Introduction}

In recent years, the European Union (EU) has developed a new economic paradigm to foster the challenge of sustainability: a Circular Economy approach instead of the classical Linear Economy [1]. A specific focus is on the plastics that are identified as a priority and committed itself to "prepare a strategy addressing the challenges posed by plastics throughout the value chain and taking into account their entire life-cycle". In 2015, the EU plastic demand was 49 millions of tons, about $20 \%$ of which for the Construction and Demolition $(\mathrm{CaD})$ sector, which is one of the most challenging fields for reaching the Circular Economy Strategy objectives [2-4]. The main result of this political effort is that many European countries have implemented a framework that leads to a recycling rate of up to $90 \%$ as early as the end of 2016 . However, this will not be enough because the European Commission is working on a revision of the essential requirements for the use of plastics in CaD to ensure by 2030, all plastics will be reusable or easily recycled. Plastics in $\mathrm{CaD}$ are mainly used to produce geosynthetics, i.e., polymeric products used in contact with soil or rock and/or other geotechnical materials and mainly applied in civil and environmental engineering. This term covers a wide range of products such as geotextiles, geomembranes, geogrids, geonets, geocomposites, etc. [5]. 
Most geosynthetics are fabricated from petroleum-derived polymers such as the polyolefin and polyester family. Polypropylene (PP) covers almost the whole total production (approximately 90\%), whereas polyethylene (PE) accounts for the remaining part $[5,6]$. In the last 7 decades, the scientific effort has been focusing on the mechanical properties to make these materials more resistant to degradation by environmental stressors (e.g., air, ultra-violet (UV) radiation, bacteria) developing mineral fiber reinforced composites and using additives to improve their stability. Thus, for many applications, biodegradability was an undesirable property, because the manufactured products must guarantee long lifespan, low cost, and mechanical properties that ensure great effectiveness. However, this purpose inevitably drove to a clash with the ecological safety. In fact, polymers are heavily subject to a wide range of degradation processes. Over time and under common environmental conditions, plastic composites may degrade into micro-plastics particles (below $5 \mathrm{~mm}$ ), which persist into the soil and cause negative environmental effects [7]. Moreover, another threat for the environment is the leaching of additives from the composites. This process is particularly complex because many factors influence the loss of additives, such as UV radiation, humidity, temperature and product thickness [8].

Thus, since the last decade, there has promptly been an increasing interest for the natural and biodegradable materials as the biopolymers to replace the synthetic ones in the worldwide market. This considerable interest in biopolymers is associated with an increase of environmental awareness that has led to the scientific and industrial community to search for a good and cost-effective alternative to the conventional materials in several engineering applications [9].

Among the fully biodegradable polymers, the poly(lactic acid) or polylactide (PLA) is certainty the most promising [10]. PLA is a thermoplastic, high-strength and high-modulus polymer $[11,12]$ that has already used on large-scale production and commercialized for a wide range of fields such as food technology, medical engineering, pharmaceutical, packaging and agriculture thanks to its huge versatility [13]. Such biopolymer ensures several advantages in terms of sustainability and eco-compatibility: (i) PLA derives from renewable agriculture-based resources [14]; (ii) PLA decomposes into non-toxic substances, as water, carbon dioxide and humus [9,15] (iii) PLA degrades quite slowly [16]; and (iv) PLA is recyclable and compostable [17]. In addition, neat-PLA has been reinforced with a wide variety of natural fibers such as bamboo, banana, coir, cotton, flax, hemp, jute, kenaf, ramie, sisal, etc. $[18,19]$, and is actually used for numerous applications in automotive, aerospace, construction, civil and the sports and leisure sectors [20-22]. Nevertheless, these biopolymers are not yet adopted in geotechnical and geo-environmental engineering, even if few studies focused on geocomposites products [23,24].

In this context, the present study aims to explore the potentiality and the possibility to use biodegradable polymers, even enhanced with natural fibers, to replace the common petroleum-derivatives polymers in the production of geosynthetics for geo-environmental and geotechnical applications. For pursuing the main objective, this research joins a detailed literature review with specific laboratory measurements to provide a comprehensive and integrated framework for assessing the usability in function of the geo-environmental application. Specific purposes are:

- $\quad$ to explore the market of PLA-based materials and to analyze the recent scientific research aiming at developing innovative bioplastics. The state-of-the-art will provide a complete spectrum of the availability/progress of technology on this kind of materials and the most common applications;

- to produce prototype samples with standard geometry using biopolymers already available on the market and to repeat the chemical and mechanical characterization of these samples;

- $\quad$ to compare the prototype samples produced with different materials analyzing advantages and disadvantage. 


\section{Materials and Methods}

\subsection{State-of-the-Art: Neat-PLA and PLA-Based Materials}

PLA is a linear aliphatic thermoplastic polyester derived from lactic acid, one of the simplest chiral molecules, obtained by the fermentation of renewable and biodegradable plant species, such as corn or rice starch and sugar feedstock [25]. Lactic acid exists in form of two different stereo isomers: L- and D-lactic acid; however, when lactic acid is produced by fermentation, it is largely composed by L-isomer (PLLA) for $99.5 \%$, whereas by D-isomer for $0.5 \%$ [18]. From lactic acid, PLA can be produced through different processes: direct condensation, azeotropic dehydrative condensation or ring-opening polymerization [26].

Physical and mechanical properties of neat-PLA are related to its composition (i.e., isomers), processing temperature, annealing, time and molecular weight [27]. Hardness, stiffness, crease, and melting points are linked to the crystallization behavior, which in turn depends on the stereochemistry and thermal history. Among all factors influencing the mechanical properties of neat-PLA, the polymerization process does not apparently cause significant variations [11]. Such mechanical properties have been largely investigated since the late 1990s, thus large amount of data is available from scientific literature, and producer's technical sheets (Table 1). On average, neat-PLA has good mechanical properties: a tensile strength (TS) from 23 to $70 \mathrm{MPa}$, a tensile modulus or Young's modulus (YM) from 2.3 to $3.8 \mathrm{GPa}$, and an elongation at break (EL) about $4 \%$. Such variability mainly depends on the polymer characteristics, such as molecular weight and specific gravity. Since the neat-PLA cannot always meet all the requirements for different fields, a common solution consists of incorporating natural fibers for improving specific properties [28-33]. However, a significant gap appears when comparing the measurements of mechanical properties on the neat-PLA with PLA blended with natural fibers, especially in terms of data availability. Most of studies have been recently carried out since a decade ago and have been summarized in Table 2.

The results of these studies underlined how the mechanical properties of the biocomposites can be significantly altered by constituent structures, contents, and production process. In several cases, the addition of natural fibers to neat-PLA improved the tensile resistance of the polymer up to $80-100 \%$ (Figure 1). Plackett et al. (2003) [34] and Ben and Kihara (2007) [35] observed an increase of TS from 55 up to more than $100 \mathrm{MPa}$ reinforcing neat-PLA with jute fibers and kenaf fibers, respectively. Excellent improvement of mechanical resistance from 7 to $17 \mathrm{MPa}$ occurred for a neat-PLA blended with corn husk and silane [36]. In addition, satisfactory results, in terms of TS, were obtained in several studies using fibers derived by herbaceous and woody plants. Molding neat-PLA and other natural fibers, Graupner et al. (2009) [37] observed an increase of TS between 37\% and 100\% using cotton and hemp fibers, according to the fiber content. Similar results were found using the ramie and flax fibers: TS increases of $+36 \%$ and of $+23 \%$, respectively [38,39]. Interesting results were obtained using also fibers derived from synthetic cellulose as rayon. Despite such encouraging results, in other cases, conversely, fiber addition to neat-PLA led to a decrease of tensile strength if compared with pure polymer, for example wood-flour addition decreased PLA TS from $67 \mathrm{MPa}$ to 40-57 MPa [40]. Also blends with milkweed, lesquerella, or cuphea were not successful in enhancing mechanical properties of PLA. 


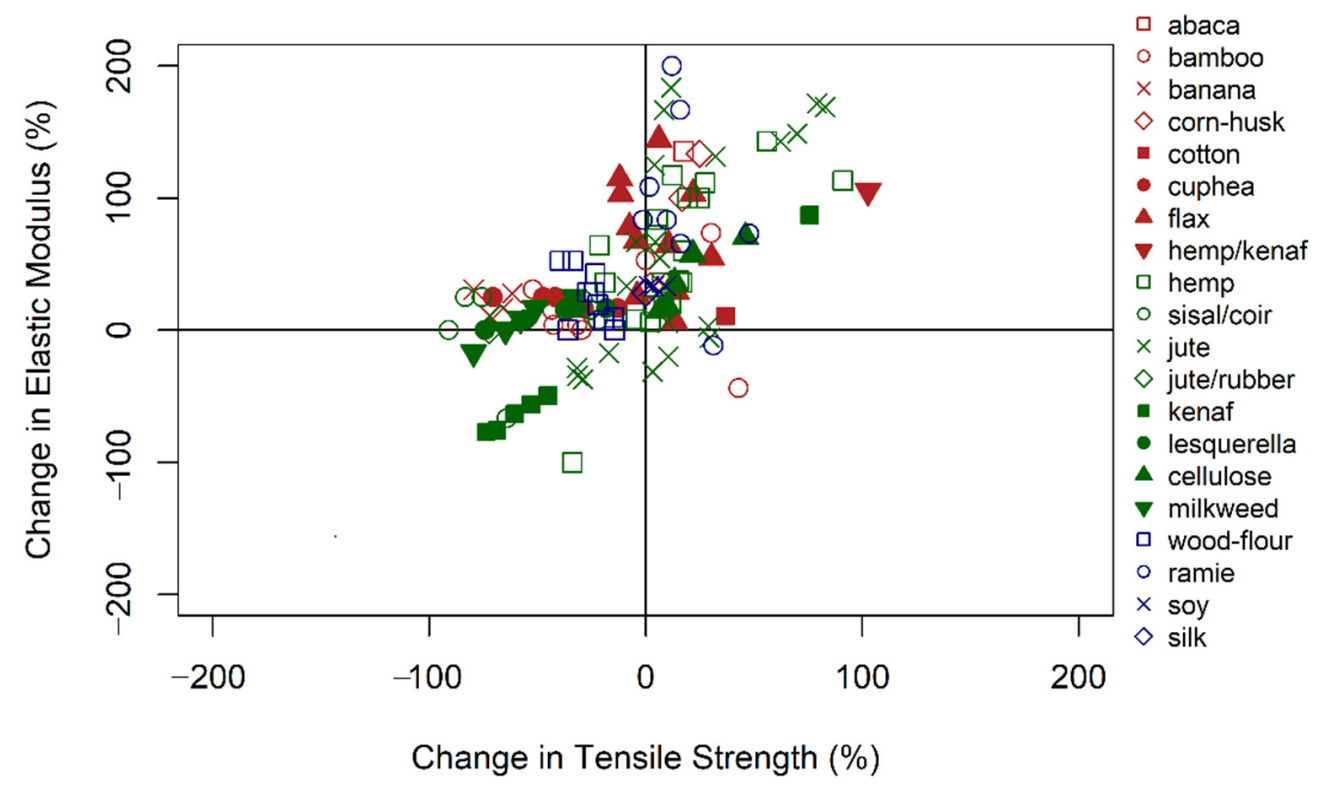

Figure 1. Change in percent in terms of Tensile Strength and Elastic Modulus measured between neat-PLA and PLA-based materials.

Table 1. Physical and mechanical characteristics of neat-PLA [41]. SG is the specific gravity, EL is the elongation at break, TS is the tensile strength and YM is the Young's modulus.

\begin{tabular}{|c|c|c|c|c|c|c|}
\hline Supplier and Product & Form & Process & $\begin{array}{l}\text { SG } \\
(g / c c)\end{array}$ & $\begin{array}{c}\text { EL } \\
(\%)\end{array}$ & $\begin{array}{c}\text { TS } \\
(\mathrm{MPa})\end{array}$ & $\begin{array}{l}\text { YM } \\
(\mathrm{GPa})\end{array}$ \\
\hline $\begin{array}{l}\text { NatureWorks Biopolymer } \\
\text { 3D850 }\end{array}$ & Filament & Extrusion-Injection molding & 1.24 & 3.3 & 50.0 & 2.3 \\
\hline $\begin{array}{c}\text { NatureWorks Biopolymer } \\
\text { 3D } 870\end{array}$ & Filament & Extrusion-Injection molding & 1.22 & 4.0 & 40.0 & 2.9 \\
\hline $\begin{array}{l}\text { NatureWorks Biopolymer } \\
\text { 4043D }\end{array}$ & Filament & Extrusion-Injection molding & 1.24 & 6.0 & 53.0 & 3.6 \\
\hline $\begin{array}{c}\text { NatureWorks Biopolymer } \\
\text { 4032D }\end{array}$ & Resin & Extrusion-Injection molding & 1.24 & 6.0 & 53.0 & 3.5 \\
\hline $\begin{array}{l}\text { NatureWorks Biopolymer } \\
\text { 4042D }\end{array}$ & Film & $\begin{array}{l}\text { Melt blending-Compression } \\
\text { molding }\end{array}$ & 1.25 & 3.6 & 56.3 & $3.3-3.8$ \\
\hline colorFabb PLA Economy & Filament & Extrusion-Injection molding & $1.20-1.30$ & 6.0 & 45.0 & 3.4 \\
\hline colorFabb SteelFill & Filament & Extrusion-Injection molding & 1.13 & $1.0-3.0$ & 23.0 & - \\
\hline $\begin{array}{l}\text { NatureWorks Biopolymer } \\
\text { 2000D }\end{array}$ & Film & Extrusion-Thermoforming & 1.25 & 6.0 & 53.0 & 3.5 \\
\hline $\begin{array}{l}\text { NatureWorks Biopolymer } \\
\text { 3010D }\end{array}$ & Film & Extrusion-Injection molding & 1.21 & 2.5 & 48.0 & - \\
\hline $\begin{array}{l}\text { NatureWorks Biopolymer } \\
\text { 2002D }\end{array}$ & Resin & Extrusion-Injection molding & 1.24 & 2.0 & 60.0 & 3.5 \\
\hline $\begin{array}{c}\text { NatureWorks Biopolymer } \\
\text { 2002D }\end{array}$ & Resin & Extrusion-Blown molding & 1.24 & 2.1 & 34.6 & 3.5 \\
\hline $\begin{array}{l}\text { NatureWorks Biopolymer } \\
4042 \mathrm{D}\end{array}$ & Film & $\begin{array}{l}\text { Melt blending-Compression } \\
\text { molding }\end{array}$ & 1.25 & 7.4 & 70.2 & 3.3 \\
\hline $\begin{array}{l}\text { NatureWorks Biopolymer } \\
\text { 4042D }\end{array}$ & Film & Extrusion-Injection molding & 1.25 & 1.0 & 38.0 & 3.8 \\
\hline $\begin{array}{l}\text { NatureWorks Biopolymer } \\
\text { 2002D }\end{array}$ & Resin & $\begin{array}{l}\text { Melt blending-Compression } \\
\text { molding }\end{array}$ & 1.24 & 4.5 & 55.0 & 3.5 \\
\hline $\begin{array}{l}\text { NatureWorks Biopolymer } \\
\text { 4032D }\end{array}$ & Resin & Extrusion-Injection molding & 1.24 & 5.0 & 65.0 & 3.5 \\
\hline $\begin{array}{l}\text { NatureWorks Biopolymer } \\
\text { 2000D }\end{array}$ & Film & Casting (chloroform) & 1.25 & 7.9 & 24.8 & 3.5 \\
\hline
\end{tabular}


Table 2. Main characteristics of PLA-based composites collected from the literature. C is the fiber content, PT is the processing temperature, TS is the tensile strength, YM is the Young's modulus, and EL is the elongation at break. In bold font, the measurements related to neat-PLA. The values in bold refer to neat-PLA.

\begin{tabular}{|c|c|c|c|c|c|c|}
\hline Reinforced-PLA & Processing & $\begin{array}{c}\mathrm{C} \\
(\%)\end{array}$ & $\begin{array}{l}\text { PT } \\
\left({ }^{\circ} \mathrm{C}\right)\end{array}$ & $\begin{array}{c}\text { TS } \\
(\mathrm{MPa})\end{array}$ & $\begin{array}{l}\mathrm{YM} \\
(\mathrm{GPa})\end{array}$ & $\begin{array}{l}\text { EL } \\
(\%)\end{array}$ \\
\hline \multirow{6}{*}{$\begin{array}{c}\text { neat-PLA blended with } \\
\text { jute fibers (Corchorus capsularis) } \\
{[34]}\end{array}$} & \multirow{6}{*}{ film-stacking } & 0 & 190 & 55.0 & 3.5 & 2.1 \\
\hline & & 40 & 180 & 72.7 & 8.1 & 1.5 \\
\hline & & 40 & 190 & 89.3 & 8.5 & 1.8 \\
\hline & & 40 & 200 & 93.5 & 8.7 & 1.6 \\
\hline & & 40 & 210 & 100.5 & 9.4 & 1.6 \\
\hline & & 40 & 220 & 98.5 & 9.5 & 1.5 \\
\hline \multirow{6}{*}{$\begin{array}{c}\text { neat-PLA blended with } \\
\text { cuphea oil-seeds } \\
\text { (Cuphea viscosissima } \times \text { C. lanceolata) } \\
{[42]}\end{array}$} & \multirow{6}{*}{ twin-screw extrusion } & 0 & 160 & 72.0 & 1.2 & 14.5 \\
\hline & & 8 & 156 & 62.6 & 1.4 & 7.8 \\
\hline & & 15 & 153 & 51.4 & 1.4 & 6.1 \\
\hline & & 22 & 155 & 41.9 & 1.5 & 5.4 \\
\hline & & 30 & 150 & 37.9 & 1.5 & 7.9 \\
\hline & & 45 & 148 & 21.2 & 1.5 & 4.6 \\
\hline \multirow{6}{*}{$\begin{array}{l}\text { neat-PLA blended with } \\
\text { lesquerella oil-seeds } \\
\text { (Lesquerella fenderli) } \\
\text { [42] }\end{array}$} & \multirow{6}{*}{ twin-screw extrusion } & 0 & 160 & 72.0 & 1.2 & 14.5 \\
\hline & & 8 & 156 & 58.9 & 1.4 & 8.8 \\
\hline & & 15 & 156 & 48.9 & 1.4 & 7.6 \\
\hline & & 22 & 155 & 45.6 & 1.4 & 5.4 \\
\hline & & 30 & 154 & 32.2 & 1.3 & 7.9 \\
\hline & & 45 & 149 & 18.5 & 1.2 & 4.6 \\
\hline \multirow{6}{*}{$\begin{array}{c}\text { neat-PLA blended with } \\
\text { milkweed oil-seeds } \\
\text { (Asclepias syriaca and Asclepias speciose) } \\
\text { [42] }\end{array}$} & \multirow{6}{*}{ twin-screw extrusion } & 0 & 160 & 72.0 & 1.2 & 14.5 \\
\hline & & 8 & 154 & 48.1 & 1.5 & 20.1 \\
\hline & & 15 & 155 & 35.2 & 1.4 & 34.6 \\
\hline & & 22 & 155 & 30.3 & 1.3 & 30.4 \\
\hline & & 30 & 155 & 25.3 & 1.2 & 23.1 \\
\hline & & 45 & 155 & 14.7 & 1.0 & 14.3 \\
\hline \multirow{12}{*}{$\begin{array}{c}\text { neat-PLA [37] } \\
\text { neat-PLA blended with } \\
\text { cotton fibers (Gossypium sp.) } \\
\text { [37] } \\
\text { neat-PLA blended with } \\
\text { kenaf fibers (Hibiscus cannabinus) } \\
\text { [37] } \\
\text { neat-PLA blended with } \\
\text { hemp fibers (Cannabis sativa) } \\
\text { [37] } \\
\text { neat-PLA blended with } \\
\text { hemp fibers (Cannabis sativa) and } \\
\text { kenaf fibers (Hibiscus cannabinus) } \\
\text { [37] }\end{array}$} & \multirow{12}{*}{ compression molding } & 0 & $160-170$ & 30.1 & 3.8 & 0.8 \\
\hline & & & & & & \\
\hline & & 40 & $160-170$ & 41.2 & 4.2 & 3.1 \\
\hline & & & & & & \\
\hline & & & & & & \\
\hline & & 40 & $160-170$ & 52.9 & 7.1 & 1.1 \\
\hline & & & & & & \\
\hline & & 40 & $160-170$ & 57.5 & 8.1 & 1.2 \\
\hline & & & & & & \\
\hline & & & & & & \\
\hline & & $20 / 20$ & $160-170$ & 61.0 & 7.8 & 1.2 \\
\hline & & $20 / 20$ & $100-1 / 0$ & & 1.0 & \\
\hline \multirow{4}{*}{$\begin{array}{c}\text { neat-PLA blended with } \\
\text { ramie fibers (Boehmeria nivea) } \\
{[32,39]}\end{array}$} & \multirow{4}{*}{$\begin{array}{l}\text { compression molding } \\
\text { twin-screw extrusion }\end{array}$} & 0 & 170 & 45.2 & 2.6 & 1.2 \\
\hline & & 30 & 170 & 52.5 & 4.3 & 3.2 \\
\hline & & $30 * *$ & 170 & 66.8 & 4.5 & 4.8 \\
\hline & & 30 & 170 & 59.3 & 2.3 & 4.1 \\
\hline neat-PLA blended with & \multirow{3}{*}{-} & 0 & 170 & 61.9 & 3.4 & \\
\hline bamboo fibers & & 35 & 170 & 80.6 & 5.9 & \\
\hline [43] & & 35 & 170 & 61.9 & 5.2 & \\
\hline \multirow{7}{*}{$\begin{array}{c}\text { neat-PLA blended with } \\
\text { hemp fibers (Cannabis sativa) } \\
{[44]}\end{array}$} & \multirow{7}{*}{ compression molding } & 0 & 170 & 35.0 & 3.5 & 6.0 \\
\hline & & $30 * *$ & 170 & 39.3 & 7.6 & \\
\hline & & 30 & 170 & 41.1 & 5.6 & \\
\hline & & $40^{* *}$ & 170 & 54.6 & 8.5 & \\
\hline & & 40 & 170 & 44.6 & 7.4 & \\
\hline & & $50 * *$ & 170 & 41.8 & 7.0 & \\
\hline & & 50 & 170 & 43.7 & 7.0 & \\
\hline
\end{tabular}


Table 2. Cont.

\begin{tabular}{|c|c|c|c|c|c|c|}
\hline Reinforced-PLA & Processing & $\begin{array}{l}\mathrm{C} \\
(\%)\end{array}$ & $\begin{array}{l}\text { PT } \\
\left({ }^{\circ} \mathrm{C}\right)\end{array}$ & $\begin{array}{c}\text { TS } \\
(\mathrm{MPa})\end{array}$ & $\begin{array}{l}\text { YM } \\
(\mathrm{GPa})\end{array}$ & $\begin{array}{l}\text { EL } \\
(\%)\end{array}$ \\
\hline $\begin{array}{c}\text { neat-PLA blended with } \\
\text { jute fibers (Corchorus capsularis) } \\
{[45]}\end{array}$ & compression molding & $\begin{array}{c}\mathbf{0} \\
5 \\
10 \\
15 \\
5 \\
10 \\
15 \\
5 \\
10 \\
15\end{array}$ & $\begin{array}{l}\mathbf{1 8 0} \\
200 \\
200 \\
200 \\
210 \\
210 \\
210 \\
220 \\
220 \\
220\end{array}$ & $\begin{array}{l}34.6 \\
23.6 \\
38.2 \\
44.8 \\
24.6 \\
35.7 \\
44.6 \\
23.7 \\
28.7 \\
38.1\end{array}$ & $\begin{array}{l}3.5 \\
2.5 \\
2.8 \\
3.3 \\
2.2 \\
2.4 \\
3.6 \\
2.3 \\
2.9 \\
3.7\end{array}$ & $\begin{array}{l}2.1 \\
6.4 \\
5.7 \\
5.8 \\
5.6 \\
5.6 \\
5.2 \\
5.6 \\
5.2 \\
5.4\end{array}$ \\
\hline $\begin{array}{c}\text { neat-PLA blended with } \\
\text { flax fibers } \\
\text { (Linum usitastissimum L. } \\
\text { and Linum Linacea) } \\
\text { [38] } \\
\text { neat-PLA blended with } \\
\text { rayon fibers [38] }\end{array}$ & $\begin{array}{l}\text { compression and } \\
\text { injection }\end{array}$ & $\begin{array}{c}\mathbf{0} \\
10 \\
20 \\
30 \\
10 \\
20 \\
30\end{array}$ & $\begin{array}{l}180 \\
180 \\
180 \\
180 \\
180 \\
180 \\
180\end{array}$ & $\begin{array}{l}44.5 \\
42.7 \\
49.2 \\
54.2 \\
50.4 \\
50.8 \\
58.0\end{array}$ & $\begin{array}{l}3.1 \\
3.9 \\
5.1 \\
6.3 \\
3.3 \\
4.0 \\
4.8\end{array}$ & \\
\hline $\begin{array}{c}\text { neat-PLA [46] } \\
\text { neat-PLA blended with } \\
\text { abaca fibers }(M u s a \text { textilis) } \\
{[46]} \\
\text { neat-PLA blended with } \\
\text { man-made cellulose fibers } \\
{[46]}\end{array}$ & $\begin{array}{l}\text { single-screw extrusion } \\
\text { and injection }\end{array}$ & $\begin{array}{l}30 \\
30\end{array}$ & $\begin{array}{l}180 \\
180\end{array}$ & $\begin{array}{l}74.0 \\
92.0\end{array}$ & $\begin{array}{l}8.0 \\
5.8\end{array}$ & \\
\hline $\begin{array}{c}\text { neat-PLA blended with } \\
\text { flax fibers (Linum usitatissimum) } \\
{[47]}\end{array}$ & $\begin{array}{c}\text { twin-screw } \\
\text { extrusion and } \\
\text { compression molding }\end{array}$ & $\begin{array}{c}0 \\
30 \\
40\end{array}$ & $\begin{array}{l}190 \\
190 \\
190\end{array}$ & $\begin{array}{l}50.0 \\
53.0 \\
44.0\end{array}$ & $\begin{array}{l}3.4 \\
8.3 \\
7.3\end{array}$ & $\begin{array}{l}2.0 \\
1.0 \\
0.9\end{array}$ \\
\hline $\begin{array}{c}\text { neat-PLA blended with } \\
\text { banana fibers (Musa indica) } \\
{[48]}\end{array}$ & compression molding & $\begin{array}{c}\mathbf{0} \\
10^{* *} \\
20^{* *} \\
30^{\text {** }} \\
40^{\text {** }}\end{array}$ & $\begin{array}{l}190 \\
190 \\
190 \\
190 \\
190\end{array}$ & $\begin{array}{c}38 \\
10.6 \\
13.0 \\
14.6 \\
7.8\end{array}$ & $\begin{array}{l}3.6 \\
4.0 \\
4.2 \\
4.6 \\
4.7\end{array}$ & $\begin{array}{l}2.9 \\
1.5 \\
1.1 \\
1.1 \\
0.9\end{array}$ \\
\hline $\begin{array}{c}\text { neat-PLA blended with } \\
\text { banana fibers (Musa indica) } \\
\text { [49] }\end{array}$ & compression molding & $\begin{array}{c}0 \\
20\end{array}$ & 185 & $\begin{array}{l}39.3 \\
46.3\end{array}$ & $\begin{array}{l}1.2 \\
6.6\end{array}$ & $\begin{array}{l}2.5 \\
0.2\end{array}$ \\
\hline $\begin{array}{c}\text { neat-PLA blended with } \\
\text { hemp fibers (Cannabis sativa) } \\
{[50]}\end{array}$ & hot pressing & $\begin{array}{c}0 \\
6 \\
20\end{array}$ & $\begin{array}{l}170 \\
170\end{array}$ & $\begin{array}{l}58.8 \\
65.7 \\
68.7\end{array}$ & $\begin{array}{l}2.5 \\
3.0 \\
3.4\end{array}$ & \\
\hline $\begin{array}{c}\text { neat-PLA blended with } \\
\text { kenaf fibers (Hibiscus cannabinus) } \\
{[35]}\end{array}$ & hot pressing & $\begin{array}{c}0 \\
38 \\
\end{array}$ & 185 & $\begin{array}{c}55.4 \\
111.6\end{array}$ & $\begin{array}{l}1.4 \\
5.9\end{array}$ & $\begin{array}{l}4.8 \\
2.7\end{array}$ \\
\hline $\begin{array}{l}\text { neat-PLA blended with } \\
\text { bamboo fibers } \\
{[51]}\end{array}$ & film-stacking & $\begin{array}{c}\mathbf{0} \\
50\end{array}$ & 160 & $\begin{array}{c}54.3 \\
77.58\end{array}$ & $\begin{array}{l}3.2 \\
1.8\end{array}$ & $\begin{array}{l}5.3 \\
14.6\end{array}$ \\
\hline $\begin{array}{c}\text { neat-PLA blended with } \\
\text { wood-flour } \\
{[40]}\end{array}$ & hot pressing & $\begin{array}{c}\mathbf{0} \\
10 \\
20 \\
30 \\
40 \\
50 \\
60\end{array}$ & $\begin{array}{l}200 \\
200 \\
200 \\
200 \\
200 \\
200\end{array}$ & $\begin{array}{l}67.4 \\
57.5 \\
52.5 \\
51.4 \\
49.3 \\
44.8 \\
40.7\end{array}$ & $\begin{array}{l}2.1 \\
2.3 \\
2.5 \\
2.7 \\
2.7 \\
3.2 \\
3.2\end{array}$ & $\begin{array}{l}5.1 \\
3.4 \\
2.9 \\
2.4 \\
2.5 \\
1.9 \\
1.8\end{array}$ \\
\hline
\end{tabular}


Table 2. Cont

\begin{tabular}{|c|c|c|c|c|c|c|}
\hline Reinforced-PLA & Processing & $\begin{array}{c}\mathrm{C} \\
(\%)\end{array}$ & $\begin{array}{l}\text { PT } \\
\left({ }^{\circ} \mathrm{C}\right)\end{array}$ & $\begin{array}{c}\text { TS } \\
(\mathrm{MPa})\end{array}$ & $\begin{array}{l}\text { YM } \\
(\mathrm{GPa})\end{array}$ & $\begin{array}{l}\text { EL } \\
(\%)\end{array}$ \\
\hline \multirow{2}{*}{$\begin{array}{c}\text { neat-PLA blended with } \\
\text { silk fibers } \\
{[21]}\end{array}$} & \multirow{2}{*}{ twin-screw extrusion } & 0 & 180 & 70.73 & 3.2 & 5.5 \\
\hline & & 5 & 180 & 70.6 & 4.1 & 3.8 \\
\hline \multirow{6}{*}{$\begin{array}{c}\text { neat-PLA blended with } \\
\text { kenaf fibers (Hibiscus cannabinus) } \\
{[52]}\end{array}$} & \multirow{6}{*}{ hot pressing } & 0 & 180 & 58.2 & 8.7 & 1.9 \\
\hline & & 10 & 180 & 23.0 & 3.2 & \\
\hline & & 20 & 180 & 27.3 & 3.8 & \\
\hline & & 30 & 180 & 31.9 & 4.4 & 0.7 \\
\hline & & 40 & 180 & 18.2 & 2.1 & \\
\hline & & 50 & 180 & 15.3 & 2.0 & \\
\hline \multirow{6}{*}{$\begin{array}{l}\text { neat-PLA blended with } \\
\text { bamboo fibers } \\
{[53]}\end{array}$} & \multirow{6}{*}{ compression molding } & 0 & & 49.8 & 2.6 & 3.1 \\
\hline & & 10 & 180 & 35.1 & 2.6 & 2.3 \\
\hline & & 20 & 180 & 34.1 & 2.7 & 2.4 \\
\hline & & 30 & 180 & 28.6 & 2.7 & 2.6 \\
\hline & & 40 & 180 & 28.2 & 3.0 & 1.8 \\
\hline & & 50 & 180 & 23.8 & 3.4 & 1.6 \\
\hline neat-PLA & injection & 0 & 160 & 51.9 & 1.1 & 8.8 \\
\hline [54] & compression molding & 0 & 160 & 55.7 & 0.6 & 15.5 \\
\hline \multirow{2}{*}{$\begin{array}{c}\text { neat-PLA blended with } \\
\text { jute fibers (Corchorus capsularis) } \\
{[54]}\end{array}$} & injection & 20 & 160 & 55.3 & 1.7 & 4.7 \\
\hline & compression molding & 20 & 160 & 50.8 & 0.8 & 8.2 \\
\hline \multirow{2}{*}{$\begin{array}{l}\text { neat-PLA blended with } \\
\text { jute fibers (Corchorus capsularis) } \\
\text { and natural rubber [54] }\end{array}$} & injection & $20 / 10$ & 160 & 17.2 & 1.2 & 2.3 \\
\hline & compression molding & $20 / 10$ & 160 & 15.4 & 0.6 & 9.4 \\
\hline neat-PLA & \multirow{9}{*}{ single-screw extrusion } & 0 & & 7.2 & 0.5 & \\
\hline$[36]$ & & $0 * *$ & 160 & 13.7 & 0.3 & \\
\hline neat-PLA blended & & $1.5^{* *}$ & 160 & 15.0 & 0.4 & \\
\hline with corn husk & & $2.5^{* *}$ & 160 & 14.2 & 0.4 & \\
\hline$[36]$ & & $3.5^{* *}$ & 160 & 13.9 & 0.4 & \\
\hline \multirow{4}{*}{$\begin{array}{c}\text { neat-PLA blended with } \\
\text { corn husk and treated with silane } \\
{[36]}\end{array}$} & & $3 / 1.5$ & 160 & 15.0 & 0.4 & \\
\hline & & $5 / 1.5$ & 160 & 17.1 & 0.7 & \\
\hline & & $7 / 1.5$ & 160 & 16.0 & 0.6 & \\
\hline & & $10 / 1.5$ & 160 & 14.0 & 0.4 & \\
\hline neat-PLA [55] & \multirow{5}{*}{-} & 0 & & 67.3 & 3.7 & 6.6 \\
\hline neat-PLA blended with & & & & & & \\
\hline flax fibers (Linum usitatissimum) & & 20 & $190-230$ & 64.4 & 6.2 & 6.2 \\
\hline $\begin{array}{c}{[55]} \\
\text { neat-PLA blended with }\end{array}$ & & & & & & \\
\hline hemp fibers (Cannabis sativa) & & 20 & $190-230$ & 71.0 & 6.8 & 5.8 \\
\hline neat-PLA [56] & \multirow{7}{*}{ twin-screw extrusion } & 0 & & 35.1 & 2.5 & \\
\hline neat-PLA blended with & & $10^{* *}$ & 160 & 37.7 & 3.4 & \\
\hline hemp fibers (Cannabis sativa) & & $20 * *$ & 160 & 28.5 & 3.4 & \\
\hline [56] & & $30 * *$ & 160 & 23.2 & & \\
\hline neat-PLA blended with & & $10^{* *}$ & 170 & 33.5 & 2.7 & \\
\hline harakeke fibers (Phormium tenax) & & $20 * *$ & 170 & 36.8 & 4.3 & \\
\hline$[56]$ & & $30 * *$ & 170 & 27.6 & 4.1 & \\
\hline \multirow{3}{*}{$\begin{array}{c}\text { neat-PLA blended with } \\
\text { Osage orange fibers (Maclura pomifera) } \\
{[42]}\end{array}$} & \multirow{3}{*}{ single-screw extrusion } & 0 & & 57.5 & 0.6 & 18.6 \\
\hline & & 10 & $150-170$ & 49.2 & 0.6 & 11.4 \\
\hline & & 25 & $150-170$ & 36.9 & 0.6 & 8.0 \\
\hline neat-PLA blended with & \multirow{3}{*}{ injection } & 0 & & 60.1 & 3.6 & 2.4 \\
\hline flax fibers (Linum usitatissimum) & & 20 & 220 & 55.5 & 6.4 & 1.4 \\
\hline [57] & & 30 & 220 & 53.1 & 7.3 & 1.1 \\
\hline
\end{tabular}


Table 2. Cont.

\begin{tabular}{|c|c|c|c|c|c|c|}
\hline Reinforced-PLA & Processing & $\begin{array}{c}\mathrm{C} \\
(\%)\end{array}$ & $\begin{array}{l}\text { PT } \\
\left({ }^{\circ} \mathrm{C}\right)\end{array}$ & $\begin{array}{c}\text { TS } \\
(\mathrm{MPa})\end{array}$ & $\begin{array}{c}\text { YM } \\
(\mathrm{GPa})\end{array}$ & $\begin{array}{l}\text { EL } \\
(\%)\end{array}$ \\
\hline \multirow[t]{2}{*}{ neat-PLA [58] } & \multirow{11}{*}{ hot pressing } & 0 & & 45.3 & 1.2 & \\
\hline & & 10 & 170 & 47.3 & 2.0 & \\
\hline neat-PLA blended with & & 20 & 170 & 49.1 & 3.2 & \\
\hline jute fibers (Corchorus capsularis) & & 30 & 170 & 50.6 & 3.4 & \\
\hline [58] & & 40 & 170 & 47.1 & 2.7 & \\
\hline \multirow{6}{*}{$\begin{array}{c}\text { neat-PLA blended with } \\
\text { ramie fibers (Boehmeria nivea) } \\
{[58]}\end{array}$} & & 50 & 170 & 43.3 & 2.0 & \\
\hline & & 10 & 170 & 49.7 & 2.2 & \\
\hline & & 20 & 170 & 50.8 & 3.6 & \\
\hline & & 30 & 170 & 52.5 & 3.2 & \\
\hline & & 40 & 170 & 46.1 & 2.5 & \\
\hline & & 50 & 170 & 44.7 & 2.2 & \\
\hline neat-PLA blended with & \multirow{3}{*}{ injection } & 0 & & 67.9 & 4.2 & 4.4 \\
\hline wood-flour & & 7.5 & $160-170$ & 54.8 & 4.5 & 2.8 \\
\hline [59] & & 15 & $160-170$ & 52.0 & 6.0 & 2.0 \\
\hline \multirow{5}{*}{$\begin{array}{c}\text { neat-PLA blended with } \\
\text { hemp fibers (Cannabis sativa) } \\
{[60]}\end{array}$} & \multirow{5}{*}{ twin-screw extrusion } & 0 & & 51.4 & 3.2 & 4.5 \\
\hline & & 3 & $170-180$ & 52.5 & 3.4 & 4.1 \\
\hline & & $3 * *$ & $170-180$ & 55.7 & 3.8 & 3.1 \\
\hline & & 6 & $170-180$ & 53.2 & 3.8 & 2.9 \\
\hline & & $6^{* *}$ & $170-180$ & 59.3 & 4.4 & 1.8 \\
\hline \multirow{5}{*}{$\begin{array}{c}\text { neat-PLA blended with } \\
\text { microfibrillated cellulose } \\
{[61]}\end{array}$} & \multirow{5}{*}{ hot pressing } & $\mathbf{0}$ & 164 & 57.7 & 3.3 & 6.8 \\
\hline & & 3 & 164 & 61.4 & 3.8 & 2.7 \\
\hline & & 5 & 164 & 63.4 & 3.9 & 2.5 \\
\hline & & 10 & 164 & 65.4 & 4.5 & 2.2 \\
\hline & & 20 & 164 & 70.2 & 5.2 & 1.9 \\
\hline \multirow{3}{*}{$\begin{array}{c}\text { neat-PLA blended with } \\
\text { toddy palm fibers } \\
\text { (Borassus Flabellifer) } \\
{[62]}\end{array}$} & \multirow{3}{*}{ compression molding } & & & & & \\
\hline & & 0 & & 52.7 & & 2.0 \\
\hline & & 30 & 180 & 25.0 & 2.0 & 9.1 \\
\hline \multirow{5}{*}{$\begin{array}{c}\text { neat-PLA blended with } \\
\text { hybrid sisal and coir fibers } \\
{[63]}\end{array}$} & \multirow{5}{*}{$\begin{array}{l}\text { hot compression } \\
\text { molding }\end{array}$} & 0 & & 53.6 & 1.3 & \\
\hline & & 10 & 180 & 41.7 & 1.4 & \\
\hline & & 20 & 180 & 39.9 & 1.5 & \\
\hline & & 30 & 180 & 38.0 & 1.6 & \\
\hline & & 40 & 180 & 33.6 & 1.5 & \\
\hline \multirow{5}{*}{$\begin{array}{c}\text { neat-PLA blended with } \\
\text { hybrid sisal and coir fibers } \\
{[64]}\end{array}$} & \multirow{5}{*}{ hot pressing } & 0 & & 23.5 & 1.2 & 2.3 \\
\hline & & 5 & 180 & 3.9 & 1.5 & 0.4 \\
\hline & & 10 & 180 & 2.1 & 1.2 & 0.5 \\
\hline & & 20 & 180 & 5.7 & 1.5 & 0.8 \\
\hline & & 30 & 180 & 8.4 & 0.4 & 3.3 \\
\hline
\end{tabular}

** indicates that the biomaterials were alkali-treated.

\subsection{Tested Biomaterials}

This study conducted a series of analysis on 6 different biomaterials and 2 petroleumderivates. The selection was carried out considering the availability on the market, adaptability for the 3D printing process (i.e., consumables for 3D printers), eco-compatibility, and slow degradation rate. This choice allowed to produce uniaxial and biaxial prototype geogrids using a 3D printing processes. Based on the requirements, a total of 6 materials in form of $1.75 \mathrm{~mm}$ diameter filament were selected:

- $\quad$ neat-PLA filament (n-PLA; PLA, Orbi-Tech@ company, Leichlingen, Germany);

- neat-PLA filament containing co-polyesters and non-toxic additives to enhance 3D printing performance (ad-PLA; PLA NX2, Extrudr@ company, Lauterach, Austria);

- neat-PLA filament containing polymeric additives and titanium dioxide for improving the strength performance under thermal treatment (ht-PLA; HTPLA V3, Proto-Pasta@, Protoplant, Vancouver, WA, USA); 
- hemp fibers reinforced-PLA filament containing approximately $20 \%$ of raw fibers (h-PLA; HempBioPlastic, Kànesis@ $@$, MICA company, Catania, Italy);

- cork fibers reinforced-PLA filament containing approximately $20 \%$ of raw fibers (cPLA; Corkfill, ColorFabb $\odot$ company, Belfeld, The Netherlands);

- wood fibers reinforced-PLA filament containing approximately $20 \%$ of raw fibers (w-PLA; Woodfill, ColorFabb $\odot$ company, Belfeld, The Netherlands).

Moreover, PP (Renkforce $\odot$, Conrad Electronic, Hirschau, Germany) and polyethylene terephthalate glycol PETG (XYZprinting $\odot$, Taipei, Taiwan) filaments were tested and used for producing prototype geogrids for a comparison with biopolymer-based filaments and prototype samples.

\subsection{Chemical and Mechanical Characterization of Biomaterials}

A detailed characterization was carried out on the selected biomaterials. First, the chemical characterization of PLA-based samples was obtained through optical purity analysis and ${ }^{1} \mathrm{H}-\mathrm{NMR}$ spectroscopy to determinate enantiomeric ratio of the two lactic acid stereoisomers composing the PLA-based samples, and their structure. Specific optical rotation $\left([\alpha]_{\mathrm{D}}\right)$ was registered with a JASCO P-2000 polarimeter, at $25^{\circ} \mathrm{C}$ with a wavelength of $589 \mathrm{~nm}$. PLA-based samples were solubilized in chloroform $\left(\mathrm{CHCl}_{3}\right)$ at a concentration of $1.00 \mathrm{~g} / \mathrm{dL}$. If necessary, some solutions were filtered with polytetrafluoroethylene syringe filters to avoid the insoluble particulate to interfere with the polarimetric analysis. Optical purity was calculated referring to the $[\alpha]_{D}$ value of pure poly (L-lactic acid). Equation (1) defines the percentage of optical purity $(\mathrm{OP})$ :

$$
\mathrm{OP}(\%)=\frac{[\alpha]_{589}^{25}}{-156} \cdot 100
$$

where $[\alpha]$ is the specific rotation observed and -156 is the specific rotation for L-lactic acid enantiopure PLA, at a concentration of $1 \mathrm{~g} / \mathrm{dL}$ at $25^{\circ} \mathrm{C}$ [65]. NMR spectra were recorded at $25^{\circ} \mathrm{C}$ with a Bruker AV 600 spectrometer at $600 \mathrm{MHz}$. Samples were prepared solubilizing PLA in $\mathrm{CDCl} 3$ in a range of concentration of $3-6 \mathrm{mg} / \mathrm{mL}$.

Mechanical tests were performed using a Universal Testing Machine (MTS Criterion Model 44, MTS Systems Corporation, Eden Prairie, MN, USA) equipped with universal clamps (with a distance between the jaws of $10 \mathrm{~cm}$ ) that avoided sample damage at the clamping points according to ASTM D6637 standard. Tensile force (in N) was exerted by a system of gears at a rate of $10 \mathrm{~mm} / \mathrm{min}$ and it was measured as a function of the strain by a load cell (F.S. $=5000 \mathrm{~N}$ ). The tensile force at the point of rupture was taken as the peak load, and TS (MPa) was calculated by dividing the breaking force by the cross-sectional area of the filament $\left(\mathrm{mm}^{2}\right)$. For model geogrids, TS $(\mathrm{kN} / \mathrm{m})$ was calculated by dividing the breaking force by the sample width.

\subsection{Prototypes Building and Testing}

In geotechnical engineering research, the geosynthetics and in particular geogrids have been tested into physical model experiments: from the small-scale and large-scale laboratory tests to full-scale field tests. Certainly, full-scale model tests are more representative of field conditions, but they are very expensive and inevitably present difficulties associated with the model preparation [66,67]. In the literature, small-scale test results are compared to those obtained by full-scale ones [68-70]. Moreover, 3D printing has become a revolutionary technology and has proven to be an important tool for many fields of engineering applications. Thanks to the flexibility of this technology, 3D printers quickly transform theoretical design concepts into prototypes, on which it is possible to verify their feasibility. The pioneering studies that underlined how 3D printing can support geotechnical engineering are recent [71-74]. This technology allows better understanding of the mechanical behavior of innovative elements of geotechnical structures testing materials, geometries, and positions. Recently, Stathas et al. (2017) [74] using this technology, successfully fabricated and tested standard prototypes of model geogrids according to the 
technical specifications of the geotechnical literature [70,75]. The TS of model geogrids used in 1:N-reinforced soil models must be $1 / \mathrm{N}^{2}$ of that of full-scale geogrids when the test is carried out under $1-\mathrm{g}$ condition, or $\mathrm{n} / \mathrm{N}^{2}$ of that of prototype (small-scale geogrids) under $\mathrm{n}-\mathrm{g}$ condition in centrifuge tests. Please note that $\mathrm{N}$ represents the scale of a reduced model and $\mathrm{n}$ is the level of gravity that the model is subjected to; usually, $\mathrm{n}$ is set equal to $\mathrm{N}[76]$.

For this study, two model geogrids were designed and tested on a scale of 1:5 so that could be used to investigate the behavior of geosynthetics-reinforced soil structures in $5 \times g$ centrifuge models. Uniaxial and biaxial geogrids were designed scaling to 1:5 the standard dimensions of full-scale geogrids available on the market. The prototype samples were produced by a Sharebot NG 2 printer using the manufacturing technology of the fused filament fabrication (a common 3D printing process for thermoplastic materials) and the printer feedstock is a continuous filament. The dimensions of the prototype samples were $50 \mathrm{~mm}$ width $\times 150 \mathrm{~mm}$ length, and $0.5 \mathrm{~mm}$ thick, with an accuracy of $0.1 \mathrm{~mm}$. Mechanical tests were carried out on $1.75 \mathrm{~mm}$ diameter filaments and on 3D printed geogrids samples.

\section{Results}

\subsection{Chemical and Mechanical Characterization of Biomaterials}

The average $[\alpha]_{D}$ values of samples containing PLA are showed in Table 3. Neat PLA showed a specific rotation value of $-128.70 \pm 1.40^{\circ}$ that was the highest recorded followed by h-PLA and c-PLA with $-110.05 \pm 1.56^{\circ}$ and $-107.62 \pm 0.16^{\circ}$, respectively. In contrast, the lowest $[\alpha]_{D}$ values were recorded for ht-PLA and ad-PLA, with $-70.75 \pm 1.01^{\circ}$ and $-35.50 \pm 0.14^{\circ}$ respectively. Optical purity values, for being calculated on the base of $[\alpha]_{D}$, presented the same trend: n-PLA showed the highest value of $81.96 \pm 0.52 \%$ while ad-PLA the lowest, with $23.50 \pm 0.05 \%$.

Table 3. Results of chemical properties: specific rotation $[\alpha]_{D}\left({ }^{\circ}\right)$ and optical purity OP $(\%)$.

\begin{tabular}{ccc}
\hline Biomaterial & {$[\alpha]_{\mathbf{D}}\left(^{\circ}\right)$} & OP (\%) \\
\hline n-PLA & $-128.70 \pm 1.40$ & $81.96 \pm 0.52$ \\
ad-PLA & $-35.50 \pm 0.14$ & $23.50 \pm 0.05$ \\
ht-PLA & $-70.75 \pm 1.01$ & $45.73 \pm 0.18$ \\
h-PLA & $-110.05 \pm 1.56$ & $70.54 \pm 1.30$ \\
c-PLA & $-107.62 \pm 0.16$ & $68.63 \pm 0.09$ \\
w-PLA & $-102.17 \pm 0.14$ & $67.47 \pm 0.07$ \\
\hline
\end{tabular}

The structure of n-PLA was confirmed by NMR analysis in all the samples. In the protonic spectrum a quartet and a doublet were observed at 5.15 and $1.57 \mathrm{ppm}$. Those signals are typical of the $\mathrm{CH}$ and $\mathrm{CH}_{3}$ groups of the polymeric chain. In the protonic spectrum, a weak quartet at $4.35 \mathrm{ppm}$ was also visible and compatible with the terminal $\mathrm{CH}$. The results obtained by h-PLA ${ }^{1} \mathrm{H}-\mathrm{NMR}$ spectrum showed other signals in the central region, between 3.3 and $4.5 \mathrm{ppm}$, and intense high-field peaks, whereas other weak high-field peaks that could refer to compound sugars, were evident at $0.86 \mathrm{ppm}$ (triplet), at $1.23 \mathrm{ppm}$ (singlet) and $1.52 \mathrm{ppm}$ (singlet). Thanks to the filtration process, the protonic spectrum of sample ad-PLA showed higher resolution. Signals compatible with an organic compound part of the solution (about 10\%) were detected. In particular, the double triplets resonating at 4.07 and 4.38 could be attributed to methylenic structures of a polyesteric chain $\left(\mathrm{O}-\mathrm{CH}_{2}-\mathrm{CH}_{2}-\mathrm{O}-\mathrm{COO}-\right)$ and the signal at $2.31 \mathrm{ppm}$ could be ascribed to a methylene group adjacent to an esteric group $\left(\mathrm{CH}_{2}-\mathrm{COO}-\right)$. The ht-PLA spectra resulted comparable before and after filtration. The structure of PLA was confirmed but signals compatibles with lactide were detected at 1.7 and $5.0 \mathrm{ppm}$. No other organic compound was detected. The c-PLA and w-PLA samples showed similar protonic spectra overlapping the quartet signals that were detected at 5.17 and $5.24 \mathrm{ppm}$. Other signals between 1.3 and $2.7 \mathrm{ppm}$ among with polyesteric chains signals (about 10\%) were highlighted. 
From the mechanical point of view, the measurements carried out with the tensile tests provided a preliminary characterization of these materials: the results are summarized in Table 4. The filaments of n-PLA showed the most tensile resistant than the others with a TS of $51.93 \pm 2.28 \mathrm{MPa}$. Among the PLA-based polymers, the filaments of the additive-enriched PLA, i.e., ad-PLA and ht-PLA, provided a relevant tensile resistance ranging between $34 \mathrm{MPa}$ to $49 \mathrm{MPa}$. Conversely, a gap was evident comparing $\mathrm{n}-\mathrm{PLA}$ and the additive-enriched PLA with the natural fibers reinforced-PLA. In fact, h-PLA, c-PLA, and $\mathrm{w}$-PLA showed an average of TS equal to $23 \mathrm{MPa}, 28 \mathrm{MPa}$, and $29 \mathrm{MPa}$, respectively.

Table 4. Measurements of mechanical properties obtained by tensile tests: tensile strength (TS), Young modulus (YM) and elongation rate (EL).

\begin{tabular}{cccc}
\hline Biomaterial & TS (MPa) & YM (GPa) & EL (\%) \\
\hline n-PLA & $51.93 \pm 2.28$ & $2.70 \pm 1.82$ & $5.87 \pm 2.53$ \\
ad-PLA & $34.60 \pm 1.00$ & $2.89 \pm 0.72$ & $4.53 \pm 0.62$ \\
ht-PLA & $47.28 \pm 1.72$ & $3.44 \pm 0.52$ & $6.89 \pm 1.73$ \\
h-PLA & $23.00 \pm 4.56$ & $3.73 \pm 1.01$ & $3.08 \pm 1.06$ \\
c-PLA & $27.58 \pm 0.34$ & $2.74 \pm 0.67$ & $3.83 \pm 0.15$ \\
w-PLA & $28.74 \pm 0.58$ & $3.37 \pm 1.63$ & $3.80 \pm 0.71$ \\
\hline
\end{tabular}

\subsection{Prototypes Samples Building and Testing}

The prototypes were produced with a Sharebot NG2 3D printer with Fused Deposition Modeling technology overlapping two thin layers of fused material. The extrusion temperatures ranged between 190 and $220^{\circ} \mathrm{C}$ although it depends on which biomaterial must be printed. All the prototype samples met the necessary demands of accuracy in dimension variability [74]. In particular, the error was $\pm 0.06 \mathrm{~mm}$ along the planar directions, whereas was $\pm 0.0025 \mathrm{~mm}$ in thickness. The excellent accuracy did not completely prevent the lack of defects, generally concentrated in the junctions. Figure 2 shows some examples of the prototype samples of geogrids produced using n-PLA and h-PLA.
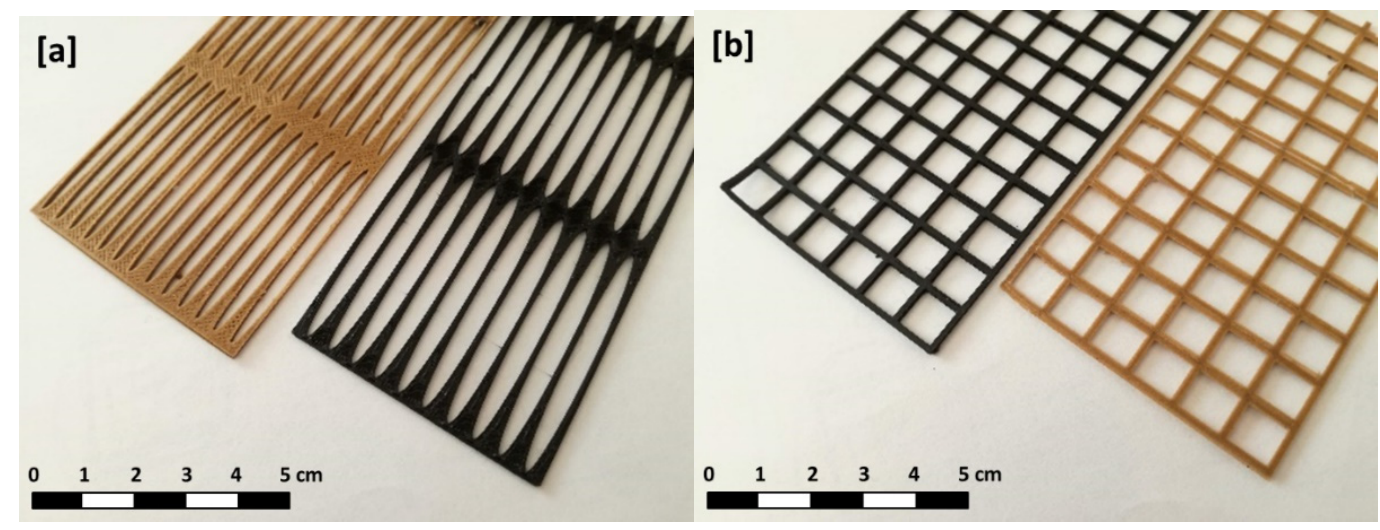

Figure 2. Examples of (a) uniaxial and (b) biaxial prototype geogrids produced using n-PLA (black) and h-PLA (brown) prototype geogrids.

As expected, evident differences were observed conducting tests on uniaxial and biaxial prototype samples. For all materials, the uniaxial geogrids provide a more consistent tensile resistance than the biaxial ones. The increase of TS varies from $48 \%$ of the n-PLA to $215 \%$ in the case of ad-PLA. Conversely, such difference is attenuated in the case of PETG and PP samples. In terms of TS, good performance was provided by n-PLA and additivesenhanced PLA prototypes. In particular, n-PLA uniaxial geogrids were characterized by an average TS of $6.76 \pm 0.19 \mathrm{kN} / \mathrm{m}$ and by a pronounced elastic deformation phase (Figure 3). Biaxial samples provided a lower value of TS $(4.56 \pm 0.75 \mathrm{kN} / \mathrm{m})$ and showed a marked with a strain at break less than $2 \%$. 


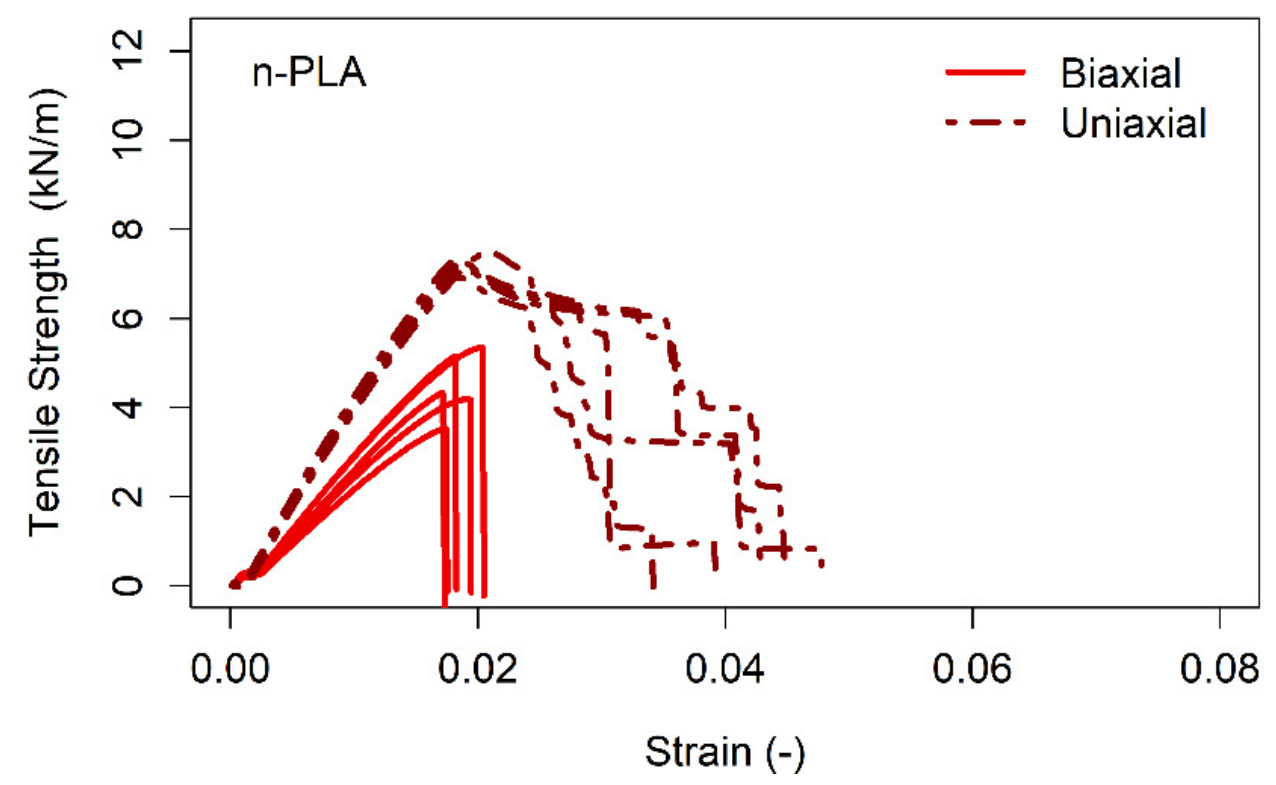

Figure 3. Stress-strain curves of n-PLA prototype geogrids: the continuous line corresponds to the biaxial samples, whereas the dotted line to the uniaxial ones.

Considering all the biomaterials, ht-PLA is the more resistant in both uniaxial and biaxial cases with TS values of $10.14 \pm 1.50 \mathrm{kN} / \mathrm{m}$ and $6.71 \pm 0.15 \mathrm{kN} / \mathrm{m}$ respectively (Figure 4). However, it was meanwhile the stiffest one. Analyzing the stress-strain curves, the plastic deformation phase seems to be completely absent and the strain at break is slightly more than $2 \%$. In the case of ad-PLA, uniaxial geogrids showed a good tensile resistance with $6.69 \pm 1.90 \mathrm{kN} / \mathrm{m}$ with an elongation at break up to $8 \%$ (Figure 5). This condition represents the best performance in terms of the elongation rate than the other prototypes produced with other biomaterials. Biaxial samples provided a lower TS $(2.12 \pm 1.26 \mathrm{kN} / \mathrm{m})$ and a significant lower strain at break. Samples of PLA-reinforced with natural fibers yielded lower values in terms of TS and the same strain rate at break, if compared to the neat biomaterial. Uniaxial prototypes made using h-PLA showed a TS of $4.44 \pm 1.26 \mathrm{kN} / \mathrm{m}$, while biaxial ones $2.73 \pm 1.08 \mathrm{kN} / \mathrm{m}$ (Figure 6). The prototypes containing hemp fibers resulted about $35 \%$ less resistant and less elastic than the corresponding in neat-PLA. In addition, h-PLA was the worst resistant biomaterial, without showing a relevant improvement in terms of elasticity. Undoubtedly, a certain uncertainty was related to the difficulties for reproducing the geometry of the prototype samples during the 3D printing process. Such fact was probably caused by the extreme stiffness of this biomaterial. Weak resistance was shown by geogrid prototypes produced with w-PLA. They did not provide satisfactory results both in tensile resistance and elasticity, with a recorded TS of $3.5 \pm 1.04 \mathrm{kN} / \mathrm{m}$ for uniaxial models and $2.84 \pm 0.73 \mathrm{kN} / \mathrm{m}$ for biaxial ones (strain at break $<2 \%$ ) (Figure 7). Conversely, c-PLA uniaxial geogrids combine a moderate TS with an encouraging strain at break compared to the PLA samples blended with the other natural fibers (hemp and wood blends) (Figure 8). TS was $4.49 \pm 1.22 \mathrm{kN} / \mathrm{m}$, whereas the elongation at break was over $8 \%$. Biaxial models produced variable stress-strain curves with lower resistant characteristics: TS was $1.93 \pm 0.53 \mathrm{kN} / \mathrm{m}$. 


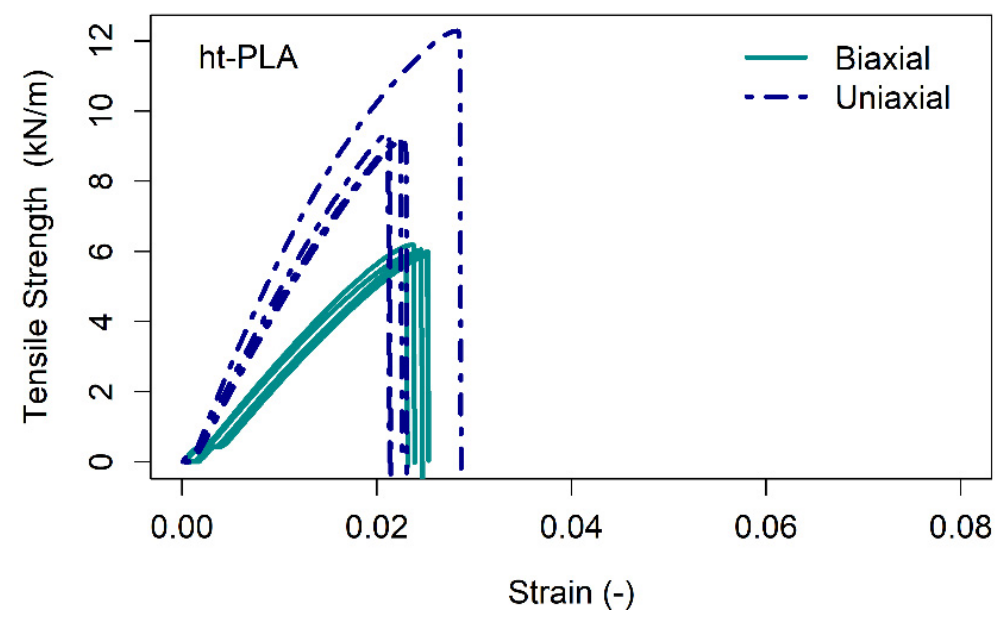

Figure 4. Stress-strain curves of ht-PLA prototype geogrids: the continuous line corresponds to the biaxial samples, whereas the dotted line to the uniaxial ones.

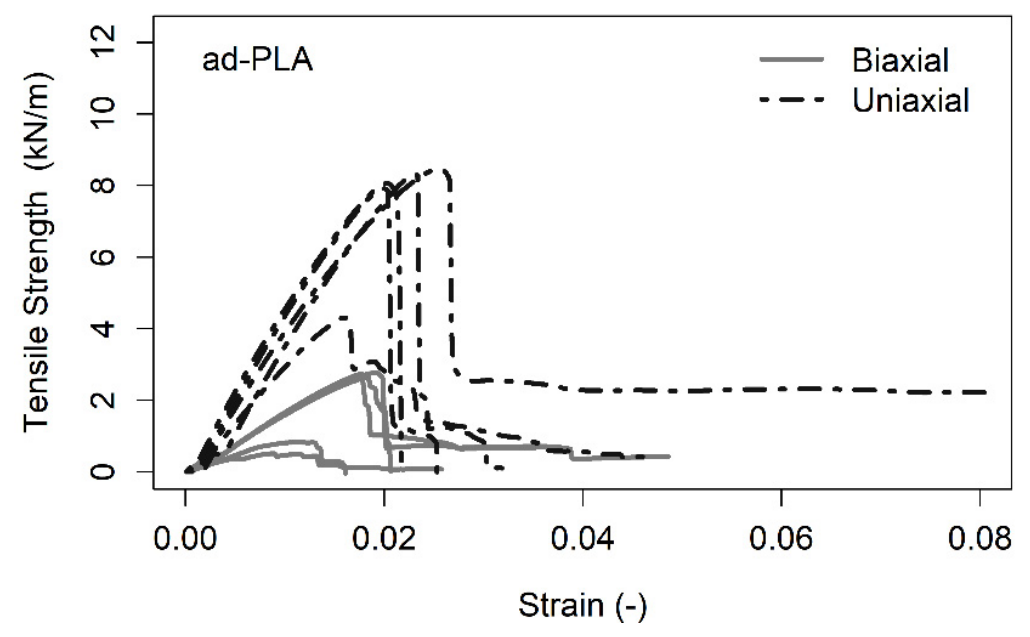

Figure 5. Stress-strain curves of ad-PLA prototype geogrids: the continuous line corresponds to the biaxial samples, whereas the dotted line to the uniaxial ones.

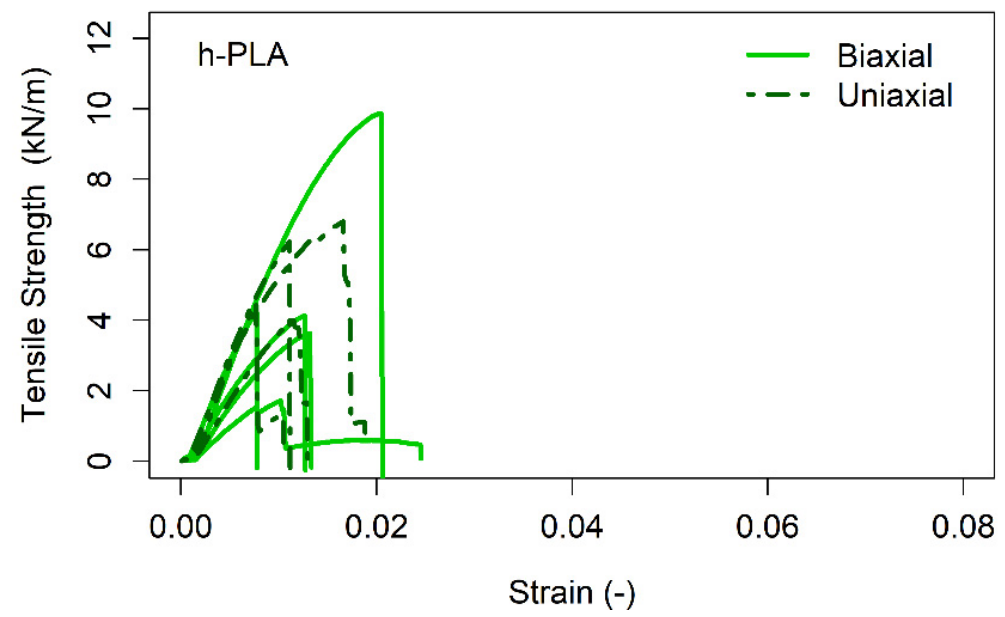

Figure 6. Stress-strain curves of h-PLA prototype geogrids: the continuous line corresponds to the biaxial samples, whereas the dotted line to the uniaxial ones. 


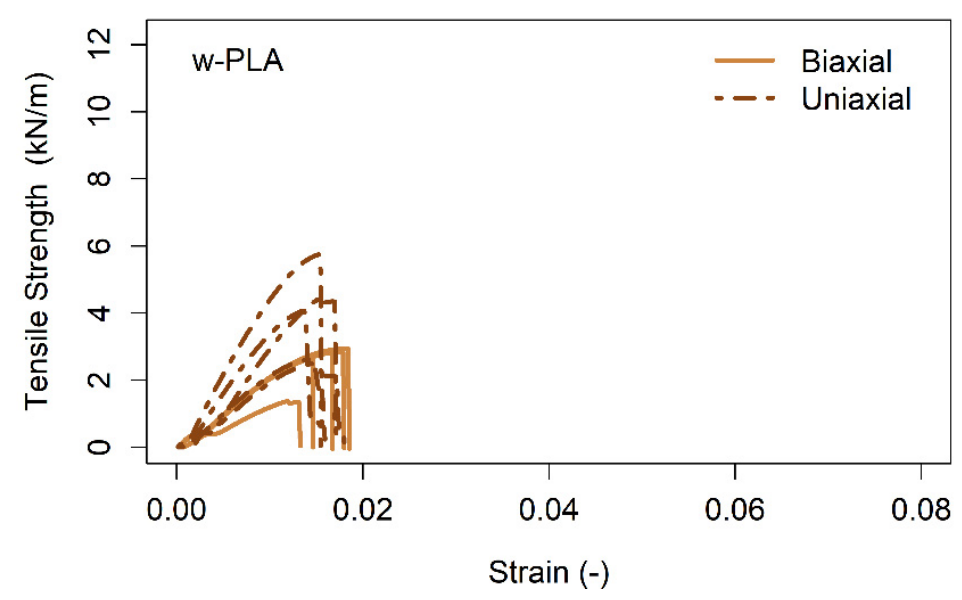

Figure 7. Stress-strain curves of w-PLA prototype geogrids: the continuous line corresponds to the biaxial samples, whereas the dotted line to the uniaxial ones.

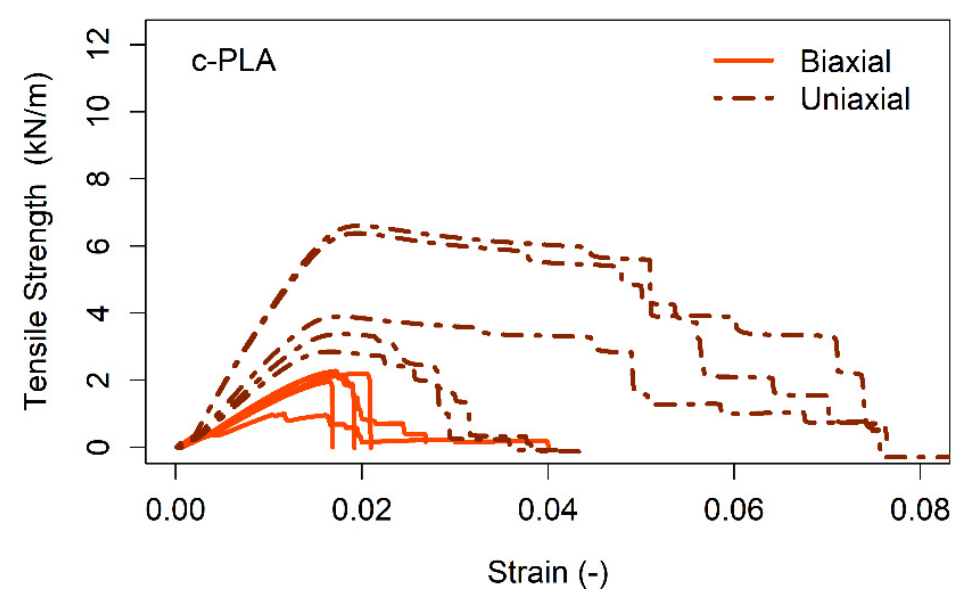

Figure 8. Stress-strain curves of c-PLA prototype geogrids: the continuous line corresponds to the biaxial samples, whereas the dotted line to the uniaxial ones.

For a comparison with the commonly used materials, additional mechanical tests were conducted on PETG and PP prototype geogrids. The results pointed out two opposite behaviors, both for uniaxial and biaxial samples. As shown in Figure 9, TS values were $5.03 \pm 0.46 \mathrm{kN} / \mathrm{m}$ and $4.89 \pm 0.46 \mathrm{kN} / \mathrm{m}$ respectively for uniaxial and biaxial geogrids, whereas the elongation at break never exceeded $3 \%$ in all cases. Such results are very similar in both the prototype configurations. On the other hand, PP geogrids were characterized by a lower TS at yield, $1.04 \pm 0.08 \mathrm{kN} / \mathrm{m}$, and by a long elastic deformation phase followed by a likewise plastic deformation phase (Figure 10) with an elongation at break of 15-20\% for the uniaxial model and $30-40 \%$ for the biaxial.

Finally, the mechanical tests conducted on the plastic-based materials allowed to compare the results and to discuss the intrinsic properties of biomaterials. PLA-natural fibers models were, on average, $35 \%$ less resistant to tension when compared with n-PLA ones; so, apparently, the geogrids geometry reduced the gap among the TS values of the biomaterials measured on the filaments. The ht-PLA made geogrids were the most tensile resistant and the only ones that presented TS values greater than n-PLA. Although the encouraging observations, all the PLA-based geogrid prototypes are very stiff. In fact, despite PP prototypes showed very low resistance to tension stress, they ensure a significant elasticity that, in some cases, must be requested for several geoengineering applications. 


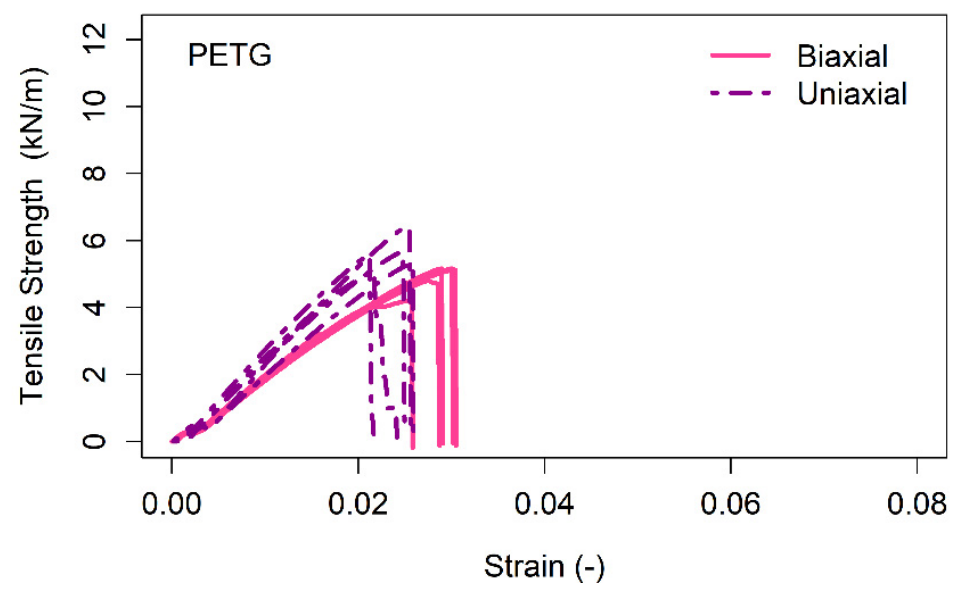

Figure 9. Stress-strain curves of PETG prototype geogrids: the continuous line corresponds to the biaxial samples, whereas the dotted line to the uniaxial ones.

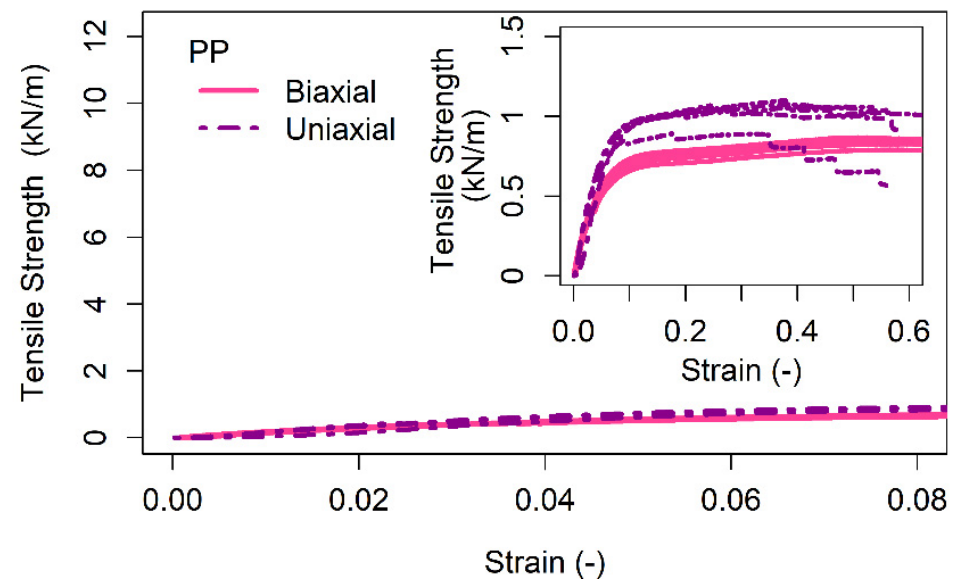

Figure 10. Stress-strain curves of PP prototype geogrids. In the inside panels, the stress-strain curves are zoomed to distinguish their characteristics. The continuous line corresponds to the biaxial samples, whereas the dotted line to the uniaxial ones.

\section{Discussion}

\subsection{An Overview of Biomaterials: From the Mechanical Properties to the Biodegradation}

Many authors have already demonstrated through observations and measurements how the PLA-based biopolymer provides better performance in terms of mechanical resistance than other plastic-derived materials as PP [25]. In the present study, the measurements confirmed that PLA-based materials, in the most of cases, are more resistant under tensile stress than PP and PETG. In addition, it is significant how PP showed the lowest TS. Conversely, as expected, PLA and its blends showed to be very brittle with a scarce elongation at break. All tested materials exhibited an average elongation rate at break approximately to $2 \%, 600$ times smaller than PP. This evidence causes some restrictions in its application and especially in civil engineering where the materials have to guarantee plastic deformation under high stress [16].

Concerning the integration of natural fibers, a discrepancy is evident between additiveenriched PLA filaments (ad-PLA and ht-PLA) and PLA-natural fibers blends (h-PLA, $c$-PLA and w-PLA). The natural fibers that integrated the neat-PLA matrix showed a maximum TS (23-28 MPa) lower than the n-PLA, partially offset by an increase of elasticity (approximately $3 \mathrm{GPa}$ of YM) [77]. Thus, the present study did not assure that integrating PLA matrix with natural fibers provides noticeable advantages in terms of physical and mechanical properties respect than the neat material. 
This range of values agree with other experiences conducted on PLA-based materials (Table 2) and includes the effects due to several factors such as the technology of 3D printer, the production process, the constituent structure, and contents. In particular, the different fabrication processes (fused deposition modeling, powder bed fusion, inject printing, stereolithography, direct energy deposition, laminated object manufacturing) are of relevant importance [78-80]. Among this variety of methods, however, the fused filament fabrication, the most used in the maker community and adopted in the present study, offers many advantages among which a relatively low melting point and a low request of energy [81]. Nevertheless, 3D process can induce an excessive porosity and crystallization among the layers, affecting the quality of the final product. To reduce the defects and improve the mechanical properties, a heat treatment post-3D printing could be an effective solution [82].

Another element of discussion is the degradability of PLA-based materials. The degradation of PLA can occur through abiotic process by the hydrolysis and/or biotic process by bacterial, fungal, and enzymatic activities. PLA clearly shows its eco-compatible characteristics decomposing into water, carbon dioxide and humus [15,17,83]. Despite its eco-friendly nature, PLA is moderately resistant to degradation processes, although can be influenced by several factors, including PLA own properties, as molecular weight and crystallinity, and environmental factors, such as humidity, temperature, $\mathrm{pH}$ and UV light [26]. For civil engineering applications, it is important to verify the biodegradation into the soil. On this topic, several studies carrying out soil burial tests investigated the decomposition of PLA under different shapes and its composites [64,84]. Generally, 1-year burial leads to minimal degradation under natural conditions $\left(25^{\circ} \mathrm{C}\right)$ [85-87]. Generally, PLA degradation in soil is slower than in compost medium because the latter usually has a higher moisture content and temperature range, enhancing PLA hydrolysis and assimilation by thermophilic microorganisms [88]. In addition, Calmon et al. (1999) [89] monitored the biodegradability of PLA films over 20 months showing minimal degradation or finding clear signs only after 2 years.

\subsection{Applications in Geo-Environmental Engineering}

In the field of geo-environmental applications, the present study encourages the application of PLA-based materials to replace the most widely used petroleum-based materials as geosynthetics. They could be an excellent solution where it is required to perform a particular function for a limited time. A set of common applications can be: (i) containment, where it is important to limit the soil or sediment losses of a specific geometry; (ii) protection layers, where localized stresses cause damages to the soil surface; (iii) soil reinforcement, where the application consists of increasing the soil resistance to the sediment mobilization; (iv) erosion control, where surface erosion of soil particles is commonly due to surface water runoff and/or wind forces; and (v) frictional interlayer, where it is necessary to increase the friction at the interface between two different soil layers. Moreover, besides the optimum compatibility with the use in semi-natural and natural environment, PLA-based materials can promote the plant growth, especially the root system, through their degradation [90]. It is precisely such combination that could be the basis for designing a wide variety of soil-bioengineering measures. Among them, the geosynthetics reinforcing soil structures with vegetated face steep slopes remain the most common solution promoted by landscape engineers for the erosion control and the stabilization of the shallower soil layer [91,92]. To establish a permanent vegetation cover, seeding and live planting are the widely used method [93]. Seeding or hydro-seeding is traditionally recommended for a rapid slope-land revegetation [94], whereas the live planting that consists of installing unrooted cuttings vertically or perpendicularly to the slopes, is more expensive. Plant roots growing into the geogrids apertures can help to stabilize the soil shallower layer binding soil particles, increasing soil aggregation and anchoring the crossed soil mass to the fractures into the bedrock [93,95-99]. In addition, the vegetation cover minimizes the kinetic energy of raindrops, reduces runoff, and especially contrasts the soil erosion [100-104]. The vege- 
tation contribution increases with increasing plant growth (and root system growth) and can compensate the degradation of the mechanical performance of PLA-based geogrids over the time. According to this proposal, adopting the PLA-based materials in the geoenvironmental engineering practice allows the pursuit of the geotechnical objective (i.e., soil stabilization, erosion control) and the ecological-environmental purposes.

\section{Conclusions}

In the present study, laboratory tests were conducted on some biodegradable biopolymer based on PLA to characterize their properties in view of their use for geosynthetics production, as an alternative to petroleum-based polymers. An investigation on the global market of the bioplastics revealed how the PLA-based materials are the most promising for a wide range of applications in different fields (e.g., packaging, automotive products, consumer handled items, medical devices, etc.). Among a wide variety of biodegradable materials available on the market, 6 different PLA-based materials and 2 petroleumderivatives were selected as the best candidate for the applications in geo-environmental engineering practice. Chemical and mechanical tests carried out on filaments (adapt for the $3 \mathrm{D}$ printing) showed a tensile resistance ranging from 23 to $52 \mathrm{MPa}$ and an elastic modulus from 2.0 to $3.7 \mathrm{GPa}$ with the presence of L-lactic acid that varies from 23.5 to $82.0 \%$.

Furthermore, the production of uniaxial and biaxial small-scaled standard geogrids through a 3D printer allowed a robust comparison among them and among other materials as PETG and PP. As expected, the uniaxial geogrids were approximately $90 \%$ more resistant than the biaxial ones, considering all the tested cases. Among PLA-based, n-PLA and ht-PLA (i.e., with titanium dioxide) showed the best performance in terms of TS, $6.76 \mathrm{kN} / \mathrm{m}$ and $10.14 \mathrm{kN} / \mathrm{m}$, respectively. Such values are approximately two times higher than the same prototype samples produced by PETG and are much higher than those guaranteed by PP geogrids. Despite the higher TS, PLA-based prototype samples were less elastic than those produced by PP that present an elongation at break up to $25 \%$.

Finally, the biodegradable PLA or PLA-based polymers could be reliable and robust materials for the use in the field of geo-environmental (civil, geotechnical and soil-bio) engineering. Further investigations on their mechanical degradation under different field conditions (water, soil, rooted-soil, etc.) to verify their durability, will allow the establishment of whether these materials may actually represent an alternative to the petroleumbased products that cause serious impacts on the environment. Clearly, there is still a gap in terms of tensile strength between biopolymer-made and petroleum-based geosynthetics, but their use in combination with live plants, where the root system development initially supports and then gradually substitutes the biodegradable products in soil reinforcement, represents a promising research field.

Author Contributions: Conceptualization, A.C., P.S., C.G., and G.B.B.; methodology, A.C., P.S., and G.B.; software, A.C. and P.S.; validation, A.C., P.S. and G.B.; formal analysis, A.C., P.S. and G.B.; investigation, A.C., P.S. and G.B.B.; resources, C.G. and G.B.B.; data curation, A.C., P.S. and G.B.; writing—original draft preparation, A.C. and P.S.; writing—review and editing, A.C., P.S., G.B., C.G., and G.B.B; visualization, A.C. and P.S.; supervision, C.G. and G.B.B.; project administration, C.G. and G.B.B.; funding acquisition, C.G. and G.B.B. All authors have read and agreed to the published version of the manuscript.

Funding: This research was an integral part of the project TREE:HERO, acronym of "TREE distribution patterns: HillslopE failuRe prevention through forest management", entirely funded by Fondazione Cariplo (Italy; Ref. 2017-0714) in the framework of "Research dedicated to hydrogeological instability: a contribution to the prevision, prevention and risk mitigation".

Acknowledgments: The authors thank the Special Issue Editor Slobodan Mickovski and the two anonymous reviewers for their suggestions and comments.

Conflicts of Interest: The authors declare no conflict of interest. 


\section{References}

1. European Commission. COM(2014) 398 Final; Towards a Circular Economy: A ZeroWaste Programme for Europe; European Commission: Brussels, Belgium, 2014; p. 14.

2. Huang, B.; Wang, X.; Kua, H.; Geng, Y.; Bleischwitz, R.; Ren, J. Construction and Demolition Waste Management in China through the 3R Principle. Resour. Conserv. Recycl. 2018, 129, 36-44. [CrossRef]

3. Lu, W.; Yuan, H. A Framework for Understanding Waste Management Studies in Construction. Waste Manag. 2011, 31, 1252-1260. [CrossRef]

4. European Commission. COM(2018) 35 Final; On the Impact of the Use of Oxo-Degradable Plastic, Including Oxo-Degradable Plastic Carrier Bags, On the Environment; European Commission: Brussels, Belgium, 2018; p. 9.

5. Wiewel, B.V.; Lamoree, M. Geotextile Composition, Application and Ecotoxicology: A Review. J. Hazard. Mater. 2016, 317, 640-655. [CrossRef] [PubMed]

6. Müller, W.W.; Saathoff, F. Geosynthetics in Geoenvironmental Engineering. Sci. Technol. Adv. Mater. 2015, 16, 034605. [CrossRef]

7. Browne, M.A.; Galloway, T.; Thompson, R. Microplastic-an Emerging Contaminant of Potential Concern?: Learned Discourses. Integr. Environ. Assess. Manag. 2007, 3, 559-561. [CrossRef]

8. Beißmann, S.; Stiftinger, M.; Grabmayer, K.; Wallner, G.; Nitsche, D.; Buchberger, W. Monitoring the Degradation of Stabilization Systems in Polypropylene during Accelerated Aging Tests by Liquid Chromatography Combined with Atmospheric Pressure Chemical Ionization Mass Spectrometry. Polym. Degrad. Stab. 2013, 98, 1655-1661. [CrossRef]

9. Avella, M.; Buzarovska, A.; Errico, M.; Gentile, G.; Grozdanov, A. Eco-Challenges of Bio-Based Polymer Composites. Materials 2009, 2, 911-925. [CrossRef]

10. Pozo Morales, A.; Güemes, A.; Fernandez-Lopez, A.; Carcelen Valero, V.; De La Rosa Llano, S. Bamboo-Polylactic Acid (PLA) Composite Material for Structural Applications. Materials 2017, 10, 1286. [CrossRef] [PubMed]

11. Farah, S.; Anderson, D.G.; Langer, R. Physical and Mechanical Properties of PLA, and Their Functions in Widespread Applications: A Comprehensive Review. Adv. Drug Deliv. Rev. 2016, 107, 367-392. [CrossRef] [PubMed]

12. Gowthaman, S.; Nakashima, K.; Kawasaki, S. A State-of-the-Art Review on Soil Reinforcement Technology Using Natural Plant Fiber Materials: Past Findings, Present Trends and Future Directions. Materials 2018, 11, 553. [CrossRef] [PubMed]

13. Garlotta, D. A Literature Review of Poly(Lactic Acid). J. Polym. Environ. 2001, 9, 63-84. [CrossRef]

14. Jamshidian, M.; Tehrany, E.A.; Imran, M.; Jacquot, M.; Desobry, S. Poly-Lactic Acid: Production, Applications, Nanocomposites, and Release Studies. Compr. Rev. Food Sci. Food Saf. 2010, 9, 552-571. [CrossRef] [PubMed]

15. Tuominen, J.; Kylmä, J.; Kapanen, A.; Venelampi, O.; Itävaara, M.; Seppälä, J. Biodegradation of Lactic Acid Based Polymers under Controlled Composting Conditions and Evaluation of the Ecotoxicological Impact. Biomacromolecules 2002, 3, 445-455. [CrossRef]

16. Rasal, R.M.; Janorkar, A.V.; Hirt, D.E. Poly(Lactic Acid) Modifications. Prog. Polym. Sci. 2010, 35, 338-356. [CrossRef]

17. Drumright, R.E.; Gruber, P.R.; Henton, D.E. Polylactic Acid Technology. Adv. Mater. 2000, 12, 1841-1846. [CrossRef]

18. Farrington, D.W.; Davies, J.L.S.; Blackburn, R.S. Poly(lactic acid) fibers. In Biodegradable and Sustainable Fibres; Elsevier: Amsterdam, The Netherlands, 2005; pp. 191-220. ISBN 978-1-85573-916-1.

19. Pickering, K.L.; Aruan Efendy, M.G.; Le, T.M. A Review of Recent Developments in Natural Fibre Composites and Their Mechanical Performance. Compos. Part A Appl. Sci. Manuf. 2016, 83, 98-112. [CrossRef]

20. Faruk, O.; Bledzki, A.K.; Fink, H.-P.; Sain, M. Biocomposites Reinforced with Natural Fibers: 2000-2010. Prog. Polym. Sci. 2012, 37, 1552-1596. [CrossRef]

21. Ho, M.; Lau, K.; Wang, H.; Bhattacharyya, D. Characteristics of a Silk Fibre Reinforced Biodegradable Plastic. Compos. Part B Eng. 2011, 42, 117-122. [CrossRef]

22. Uddin, N.; Kalyankar, R.R. Manufacturing and Structural Feasibility of Natural Fiber Reinforced Polymeric Structural Insulated Panels for Panelized Construction. Int. J. Polym. Sci. 2011, 2011, 1-7. [CrossRef]

23. Bhatraju, N.S.; Kumar, K.K. To Learn on Construction of Pavement by Using Geotextile. Int. J. Innov. Technol. Res. 2018, $6,7867-7869$.

24. Jeon, H.-Y. Environmental Adaptability of Green Geosynthetics as Sustainable Materials for Civil Engineering Applications. In Proceedings of the Geosynthetics, Forging a Path to Bona Fide Engineering Materials; American Society of Civil Engineers: Chicago, IL, USA, 2016; pp. 318-325.

25. Murariu, M.; Dubois, P. PLA Composites: From Production to Properties. Adv. Drug Deliv. Rev. 2016, 107, 17-46. [CrossRef] [PubMed]

26. Karamanlioglu, M.; Preziosi, R.; Robson, G.D. Abiotic and Biotic Environmental Degradation of the Bioplastic Polymer Poly(Lactic Acid): A Review. Polym. Degrad. Stab. 2017, 137, 122-130. [CrossRef]

27. Lasprilla, A.J.R.; Martinez, G.A.R.; Lunelli, B.H.; Jardini, A.L.; Filho, R.M. Poly-Lactic Acid Synthesis for Application in Biomedical Devices: A Review. Biotechnol. Adv. 2012, 30, 321-328. [CrossRef] [PubMed]

28. Gunti, R.; Ratna Prasad, A.V.; Gupta, A.V.S.S.K.S. Mechanical and Degradation Properties of Natural Fiber-Reinforced PLA Composites: Jute, Sisal, and Elephant Grass. Polym. Compos. 2018, 39, 1125-1136. [CrossRef]

29. Mochane, M.J.; Mokhena, T.C.; Sadiku, E.R.; Ray, S.S.; Mofokeng, T.G. Green polymer composites based on polylactic acid (PLA) and fibers. In Green Biopolymers and Their Nanocomposites; Gnanasekaran, D., Ed.; Springer: Singapore, 2019; pp. 29-54. ISBN 9789811380624. 
30. Ochi, S. Mechanical Properties of Kenaf Fibers and Kenaf/PLA Composites. Mech. Mater. 2008, 40, 446-452. [CrossRef]

31. Sun, Z.; Zhang, L.; Liang, D.; Xiao, W.; Lin, J. Mechanical and Thermal Properties of PLA Biocomposites Reinforced by Coir Fibers. Int. J. Polym. Sci. 2017, 2017, 1-8. [CrossRef]

32. Wang, Y.; Weng, Y.; Wang, L. Characterization of Interfacial Compatibility of Polylactic Acid and Bamboo Flour (PLA/BF) in Biocomposites. Polym. Test. 2014, 36, 119-125. [CrossRef]

33. Yu, T.; Ding, D.; Sheng, C.; Tuerhongiiang, T.; Li, Y. Enhanced Mechanical Properties and Flame Retardancy of Short Jute Fiber/Poly(Lactic Acid) Composites with Phosphorus-Based Compound. Sci. China Technol. Sci. 2017, 60, 1716-1723. [CrossRef]

34. Plackett, D.; Løgstrup Andersen, T.; Batsberg Pedersen, W.; Nielsen, L. Biodegradable Composites Based on L-Polylactide and Jute Fibres. Compos. Sci. Technol. 2003, 63, 1287-1296. [CrossRef]

35. Ben, G.; Kihara, Y. Development and Evaluation of Mechanical Properties for Kenaf Fibers/PLA Composites. Key Eng. Mater. 2007, 334-335, 489-492. [CrossRef]

36. Saenghirunwattana, P.; Noomhorm, A.; Rungsardthong, V. Mechanical Properties of Soy Protein Based “Green" Composites Reinforced with Surface Modified Cornhusk Fiber. Ind. Crop. Prod. 2014, 60, 144-150. [CrossRef]

37. Graupner, N.; Herrmann, A.S.; Müssig, J. Natural and Man-Made Cellulose Fibre-Reinforced Poly(Lactic Acid) (PLA) Composites: An Overview about Mechanical Characteristics and Application Areas. Compos. Part A Appl. Sci. Manuf. 2009, 40, 810-821. [CrossRef]

38. Bax, B.; Müssig, J. Impact and Tensile Properties of PLA/Cordenka and PLA/Flax Composites. Compos. Sci. Technol. 2008, 68, 1601-1607. [CrossRef]

39. Yu, T.; Ren, J.; Li, S.; Yuan, H.; Li, Y. Effect of Fiber Surface-Treatments on the Properties of Poly(Lactic Acid)/Ramie Composites. Compos. Part A Appl. Sci. Manuf. 2010, 41, 499-505. [CrossRef]

40. Febrianto, F.; Yoshioka, M.; Nagai, Y.; Syafii, W.; Shiraishi, N. Characterization and Properties of Composites of Wood Flour and Poly Lactic Acid. Mokchae Konghak 2006, 34, 67-78.

41. Muller, J.; González-Martínez, C.; Chiralt, A. Combination of Poly(Lactic) Acid and Starch for Biodegradable Food Packaging. Materials 2017, 10, 952. [CrossRef] [PubMed]

42. Finkenstadt, V.L.; Liu, C.-K.; Evangelista, R.; Liu, L.; Cermak, S.C.; Hojilla-Evangelista, M.; Willett, J.L. Poly(Lactic Acid) Green Composites Using Oilseed Coproducts as Fillers. Ind. Crop. Prod. 2007, 26, 36-43. [CrossRef]

43. Rawi, N.F.M.; Jayaraman, K.; Bhattacharyya, D. A Performance Study on Composites Made from Bamboo Fabric and Poly(Lactic Acid). J. Reinf. Plast. Compos. 2013, 32, 1513-1525. [CrossRef]

44. Hu, R.; Lim, J.-K. Fabrication and Mechanical Properties of Completely Biodegradable Hemp Fiber Reinforced Polylactic Acid Composites. J. Compos. Mater. 2007, 41, 1655-1669. [CrossRef]

45. Ma, H.; Joo, C.W. Structure and Mechanical Properties of Jute-Polylactic Acid Biodegradable Composites. J. Compos. Mater. 2011, 45, 1451-1460. [CrossRef]

46. Bledzki, A.K.; Jaszkiewicz, A.; Scherzer, D. Mechanical Properties of PLA Composites with Man-Made Cellulose and Abaca Fibres. Compos. Part A Appl. Sci. Manuf. 2009, 40, 404-412. [CrossRef]

47. Oksman, K.; Skrifvars, M.; Selin, J.-F. Natural Fibres as Reinforcement in Polylactic Acid (PLA) Composites. Compos. Sci. Technol. 2003, 63, 1317-1324. [CrossRef]

48. Jandas, P.J.; Mohanty, A.K.; Nayak, S.K.; Srivastava, H. Effect of Surface Treatments of Banana Fiber on Mechanical, Thermal, and Biodegradability Properties of PLA/Banana Fiber Biocomposites. Polym Compos 2011, 32, 1689-1700. [CrossRef]

49. Shih, Y.-F.; Huang, C.-C. Polylactic Acid (PLA)/Banana Fiber (BF) Biodegradable Green Composites. J. Polym. Res. 2011, 18, 2335-2340. [CrossRef]

50. Song, Y.S.; Lee, J.T.; Ji, D.S.; Kim, M.W.; Lee, S.H.; Youn, J.R. Viscoelastic and Thermal Behavior of Woven Hemp Fiber Reinforced Poly(Lactic Acid) Composites. Compos. Part B Eng. 2012, 43, 856-860. [CrossRef]

51. Porras, A.; Maranon, A. Development and Characterization of a Laminate Composite Material from Polylactic Acid (PLA) and Woven Bamboo Fabric. Compos. Part B Eng. 2012, 43, 2782-2788. [CrossRef]

52. Ibrahim, N.A.; Yunus, W.M.Z.W.; Othman, M.; Abdan, K.; Hadithon, K.A. Poly(Lactic Acid) (PLA)-Reinforced Kenaf Bast Fiber Composites: The Effect of Triacetin. J. Reinf. Plast. Compos. 2010, 29, 1099-1111. [CrossRef]

53. Lee, S.-H.; Wang, S. Biodegradable Polymers/Bamboo Fiber Biocomposite with Bio-Based Coupling Agent. Compos. Part A: Appl. Sci. Manuf. 2006, 37, 80-91. [CrossRef]

54. Ruksakulpiwat, Y.; Tonimit, P.; Kluengsamrong, J. Mechanical Properties of PLA-Jute Composites by Using Natural Rubber and Epoxidized Natural Rubber as Impact Modifiers: Effect of Molding Technique. Clean Technol. 2010, 4, 310-313.

55. Taha, I.; Ziegmann, G. A Comparison of Mechanical Properties of Natural Fiber Filled Biodegradable and Polyolefin Polymers. J. Compos. Mater. 2006, 40, 1933-1946. [CrossRef]

56. Stoof, D.; Pickering, K.; Zhang, Y. Fused Deposition Modelling of Natural Fibre/Polylactic Acid Composites. J. Compos. Sci. 2017, 1, 8. [CrossRef]

57. Le Duigou, A.; Pillin, I.; Bourmaud, A.; Davies, P.; Baley, C. Effect of Recycling on Mechanical Behaviour of Biocompostable Flax/Poly(l-Lactide) Composites. Compos. Part A Appl. Sci. Manuf. 2008, 39, 1471-1478. [CrossRef]

58. Yu, T.; Li, Y.; Ren, J. Preparation and Properties of Short Natural Fiber Reinforced Poly(Lactic Acid) Composites. Trans. Nonferrous Met. Soc. China 2009, 19, s651-s655. [CrossRef] 
59. Kuciel, S.; Mazur, K.; Hebda, M. The Influence of Wood and Basalt Fibres on Mechanical, Thermal and Hydrothermal Properties of PLA Composites. J Polym Environ. 2020, 28, 1204-1215. [CrossRef]

60. Mazzanti, V.; Pariante, R.; Bonanno, A.; Ruiz de Ballesteros, O.; Mollica, F.; Filippone, G. Reinforcing Mechanisms of Natural Fibers in Green Composites: Role of Fibers Morphology in a PLA/Hemp Model System. Compos. Sci. Technol. 2019, 180, 51-59. [CrossRef]

61. Suryanegara, L.; Nakagaito, A.N.; Yano, H. The Effect of Crystallization of PLA on the Thermal and Mechanical Properties of Microfibrillated Cellulose-Reinforced PLA Composites. Compos. Sci. Technol. 2009, 69, 1187-1192. [CrossRef]

62. Graupner, N.; Narkpiban, K.; Poonsawat, T.; Tooptompong, P.; Müssig, J. Toddy Palm (Borassus Flabellifer) Fruit Fibre Bundles as Reinforcement in Polylactide (PLA) Composites: An Overview about Fibre and Composite Characteristics. J. Renew. Mater. 2019, 7, 693-711. [CrossRef]

63. Duan, J.; Wu, H.; Fu, W.; Hao, M. Mechanical Properties of Hybrid Sisal/Coir Fibers Reinforced Polylactide Biocomposites. Polym. Compos. 2018, 39, E188-E199. [CrossRef]

64. Dong, Y.; Ghataura, A.; Takagi, H.; Haroosh, H.J.; Nakagaito, A.N.; Lau, K.-T. Polylactic Acid (PLA) Biocomposites Reinforced with Coir Fibres: Evaluation of Mechanical Performance and Multifunctional Properties. Compos. Part A Appl. Sci. Manuf. 2014, 63, 76-84. [CrossRef]

65. Marques, D.S.; Gil, M.H.; Baptista, C.M.S.G. Bulk Polytransesterification of L-Lactic Acid Esters: An Alternative Route to Synthesize Poly(Lactic Acid). J. Appl. Polym. Sci. 2012, 125, E283-E289. [CrossRef]

66. Hufenus, R.; Rueegger, R.; Banjac, R.; Mayor, P.; Springman, S.M.; Bronnimann, R. Full-Scale Field Tests on Geosynthetic Reinforced Unpaved Roads on Soft Subgrade. Geotext. Geomembr. 2006, 24, 21-37. [CrossRef]

67. Yoo, C.; Lee, D. Performance of Geogrid-Encased Stone Columns in Soft Ground: Full-Scale Load Tests. Geosynth. Int. 2012, 19, 480-490. [CrossRef]

68. Bathurst, R.J.; Vlachopoulos, N.; Walters, D.L.; Burgess, P.G.; Allen, T.M. The Influence of Facing Stiffness on the Performance of Two Geosynthetic Reinforced Soil Retaining Walls. Can. Geotech. J. 2006, 43, 1225-1237. [CrossRef]

69. Garnier, J.; Gaudin, C.; Springman, S.M.; Culligan, P.J.; Goodings, D.; Konig, D.; Kutter, B.; Phillips, R.; Randolph, M.F.; Thorel, L. Catalogue of Scaling Laws and Similitude Questions in Geotechnical Centrifuge Modelling. Int. J. Phys. Model. Geotech. 2007, 7, 01-23. [CrossRef]

70. Springman, S.M.; Bolton, M.D.; Sharma, J.; Balachandran, S. Modelling and instrumentation of a geotextile in the geotechnical centrifuge. In Proceedings of the International Symposyum on Earth Reinforcement Practice, Kyushu, Japan, 11-13 November 1992; 167, pp. 172-178.

71. Amurane, I.; Zhang, M.; Li, T.; Jiang, H. Optimization of 3D Printed Geocells Based on Numerical Simulation and Experimental Investigation. IOP Conf. Ser. Earth Environ. Sci. 2019, 233, 032043. [CrossRef]

72. Arab, M.G.; Omar, M.; Alotaibi, E.; Mostafa, O.; Naeem, M.; Badr, O. Bio-Inspired 3D-Printed Honeycomb for Soil Reinforcement. In Proceedings of the Geo-Congress 2020; American Society of Civil Engineers: Minneapolis, Minnesota, 2020; pp. $262-271$.

73. Mallett, S.D.; Matsumura, S.; David Frost, J. Additive Manufacturing and Computed Tomography of Bio-Inspired Anchorage Systems. Géotechnique Lett. 2018, 8, 219-225. [CrossRef]

74. Stathas, D.; Wang, J.P.; Ling, H.I. Model Geogrids and 3D Printing. Geotext. Geomembr. 2017, 45, 688-696. [CrossRef]

75. Viswanadham, B.V.S.; Jessberger, H.L. Centrifuge Modeling of Geosynthetic Reinforced Clay Liners of Landfills. J. Geotech. Geoenviron. Eng. 2005, 131, 564-574. [CrossRef]

76. Viswanadham, B.V.S.; König, D. Studies on Scaling and Instrumentation of a Geogrid. Geotext. Geomembr. 2004, 22, 307-328. [CrossRef]

77. Cislaghi, A.; Sala, P.; Borgonovo, G.; Gandolfi, C.; Bischetti, G.B. Biodegradable geosynthetics for geotechnical and geo-environmental engineering. In Innovative Biosystems Engineering for Sustainable Agriculture, Forestry and Food Production; Coppola, A., Di Renzo, G.C., Altieri, G., D’Antonio, P., Eds.; Lecture Notes in Civil Engineering; Springer International Publishing: Cham, Switerland, 2020; Volume 67, pp. 49-57. ISBN 978-3-030-39298-7.

78. Ngo, T.D.; Kashani, A.; Imbalzano, G.; Nguyen, K.T.Q.; Hui, D. Additive Manufacturing (3D Printing): A Review of Materials, Methods, Applications and Challenges. Compos. Part B Eng. 2018, 143, 172-196. [CrossRef]

79. Bandyopadhyay, A.; Heer, B. Additive Manufacturing of Multi-Material Structures. Mater. Sci. Eng. R Rep. 2018, 129, 1-16. [CrossRef]

80. Bose, S.; Ke, D.; Sahasrabudhe, H.; Bandyopadhyay, A. Additive Manufacturing of Biomaterials. Prog. Mater. Sci. 2018, 93, 45-111. [CrossRef] [PubMed]

81. Brenken, B.; Barocio, E.; Favaloro, A.; Kunc, V.; Pipes, R.B. Fused Filament Fabrication of Fiber-Reinforced Polymers: A Review. Addit. Manuf. 2018, 21,1-16. [CrossRef]

82. Liao, Y.; Liu, C.; Coppola, B.; Barra, G.; Di Maio, L.; Incarnato, L.; Lafdi, K. Effect of Porosity and Crystallinity on 3D Printed PLA Properties. Polymers 2019, 11, 1487. [CrossRef]

83. Ghorpade, V.M.; Gennadios, A.; Hanna, M.A. Laboratory Composting of Extruded Poly(Lactic Acid) Sheets q. Bioresour. Technol. 2001, 76, 57-61. [CrossRef]

84. Weng, Y.-X.; Jin, Y.-J.; Meng, Q.-Y.; Wang, L.; Zhang, M.; Wang, Y.-Z. Biodegradation Behavior of Poly(Butylene AdipateCo-Terephthalate) (PBAT), Poly(Lactic Acid) (PLA), and Their Blend under Soil Conditions. Polym. Test. 2013, 32, 918-926. [CrossRef] 
85. Karamanlioglu, M.; Houlden, A.; Robson, G.D. Isolation and Characterisation of Fungal Communities Associated with Degradation and Growth on the Surface of Poly(Lactic) Acid (PLA) in Soil and Compost. Int. Biodeterior. Biodegrad. 2014, 95, 301-310. [CrossRef]

86. Rudnik, E.; Briassoulis, D. Degradation Behaviour of Poly(Lactic Acid) Films and Fibres in Soil under Mediterranean Field Conditions and Laboratory Simulations Testing. Ind. Crop. Prod. 2011, 33, 648-658. [CrossRef]

87. Shogren, R.L.; Doane, W.M.; Garlotta, D.; Lawton, J.W.; Willett, J.L. Biodegradation of Starch/Polylactic Acid/Poly(HydroxyesterEther) Composite Bars in Soil. Polym. Degrad. Stab. 2003, 79, 405-411. [CrossRef]

88. Itävaara, M.; Karjomaa, S.; Selin, J.-F. Biodegradation of Polylactide in Aerobic and Anaerobic Thermophilic Conditions. Chemosphere 2002, 46, 879-885. [CrossRef]

89. Calmon, A.; Guillaume, S.; Bellon-Maurel, V.; Feuilloley, P.; Silvestre, F. Evaluation of Material Biodegradability in Real ConditionsDevelopment of a Burial Test and an Analysis Methodology Based on Numerical Vision. J. Environ. Polym. Degrad. 1999, 7, 157-166. [CrossRef]

90. Kinnersley, A.M.; Scott, T.C.; Yopp, J.H.; Whitten, G.H. Promotion of Plant Growth by Polymers of Lactic Acid. Plant Growth Regul. 1990, 9, 137-146. [CrossRef]

91. Bischetti, G.B.; Di Fidio, M.; Florineth, F. On the Origin of Soil Bioengineering. Landsc. Res. 2014, 39, 583-595. [CrossRef]

92. Cazzuffi, D.; Cardile, G.; Gioffrè, D. Geosynthetic Engineering and Vegetation Growth in Soil Reinforcement Applications. Transp. Infrastruct. Geotechnol. 2014, 1, 262-300. [CrossRef]

93. Gray, D.H.; Sotir, R.B. Biotechnical and Soil Bioengineering Slope Stabilization: A Practical Guide for Erosion Control; John Wiley \& Sons: Hoboken, NJ, USA, 1996; ISBN 978-0-471-04978-4.

94. Fox, J.L.; Bhattarai, S.P.; Gyasi-Agyei, Y. Evaluation of Different Seed Mixtures for Grass Establishment to Mitigate Soil Erosion on Steep Slopes of Railway Batters. J. Irrig. Drain Eng. 2011, 137, 624-631. [CrossRef]

95. Bischetti, G.B.; Chiaradia, E.A.; D'Agostino, V.; Simonato, T. Quantifying the Effect of Brush Layering on Slope Stability. Ecol. Eng. 2010, 36, 258-264. [CrossRef]

96. Cislaghi, A.; Giupponi, L.; Tamburini, A.; Giorgi, A.; Bischetti, G.B. The Effects of Mountain Grazing Abandonment on Plant Community, Forage Value and Soil Properties: Observations and Field Measurements in an Alpine Area. CATENA 2019, 181, 104086. [CrossRef]

97. De Baets, S.; Poesen, J.; Gyssels, G.; Knapen, A. Effects of Grass Roots on the Erodibility of Topsoils during Concentrated Flow. Geomorphology 2006, 76, 54-67. [CrossRef]

98. Gyssels, G.; Poesen, J.; Bochet, E.; Li, Y. Impact of Plant Roots on the Resistance of Soils to Erosion by Water: A Review. Prog. Phys. Geogr. 2005, 29, 189-217. [CrossRef]

99. Lian, B.; Peng, J.; Zhan, H.; Wang, X. Mechanical Response of Root-Reinforced Loess with Various Water Contents. Soil Tillage Res. 2019, 193, 85-94. [CrossRef]

100. Bastola, S.; Ishidaira, H.; Takeuchi, K. Regionalisation of Hydrological Model Parameters under Parameter Uncertainty: A Case Study Involving TOPMODEL and Basins across the Globe. J. Hydrol. 2008, 357, 188-206. [CrossRef]

101. Gray, D.H.; Leiser, A.T. Biotechnical Slope Protection and Erosion Control; Van Nostrand Reinhold Company Inc.: New York, NY, USA, 1982; ISBN 0-442-21222-4.

102. Zhang, X.; Zhao, W.; Wang, L.; Liu, Y.; Feng, Q.; Fang, X.; Liu, Y. Distribution of Shrubland and Grassland Soil Erodibility on the Loess Plateau. Int. J. Environ. Res. Public Health 2018, 15, 1193. [CrossRef]

103. Gonzalez-Ollauri, A.; Mickovski, S.B. Plant-Best: A Novel Plant Selection Tool for Slope Protection. Ecol. Eng. 2017, 106, 154-173. [CrossRef]

104. Gonzalez-Ollauri, A.; Mickovski, S.B. Using the Root Spread Information of Pioneer Plants to Quantify Their Mitigation Potential against Shallow Landslides and Erosion in Temperate Humid Climates. Ecol. Eng. 2016, 95, 302-315. [CrossRef] 